OPEN ACCESS

Edited by:

Hongbo Pan

Shanghai Ocean University, China

Reviewed by:

Rosaura Mayén-Estrada,

Universidad Nacional Autonoma

de Mexico, Mexico

Fengchao $\mathrm{Li}$,

Hebei University, China

Helmut Berger,

Consulting Engineering Office for

Ecology, Austria

${ }^{*}$ Correspondence:

Xumiao Chen

xchen@qdio.ac.cn

Weibo Song

wsong@ouc.edu.cn

Specialty section:

This article was submitted to

Marine Evolutionary Biology,

Biogeography and Species Diversity,

a section of the journal

Frontiers in Marine Science

Received: 30 October 2020

Accepted: 21 December 2020

Published: 27 January 2021

Citation:

Luo X, Huang J, Bourland WA

El-Serehy HA, Al-Farraj SA, Chen X and Song $W$ (2021) Taxonomy of

Three Oxytrichids (Protozoa,

Ciliophora, Hypotrichia), With Establishment of the New Species

Rubrioxytricha guangzhouensis spec.

nov. Front. Mar. Sci. 7:623436.

doi: 10.3389/fmars.2020.623436

\section{Taxonomy of Three Oxytrichids (Protozoa, Ciliophora, Hypotrichia), With Establishment of the New Species Rubrioxytricha guangzhouensis spec. nov.}

\author{
Xiaotian Luo', Jie Huang ${ }^{1}$, William A. Bourland ${ }^{2}$, Hamed A. El-Serehy ${ }^{3}$, \\ Saleh A. Al-Farraj ${ }^{3}$, Xumiao Chen ${ }^{4 *}$ and Weibo Song ${ }^{5,6 *}$ \\ ${ }^{1}$ Key Laboratory of Aquatic Biodiversity and Conservation of Chinese Academy of Sciences, Institute of Hydrobiology, \\ Chinese Academy of Sciences, Wuhan, China, ${ }^{2}$ Department of Biological Sciences, Boise State University, Boise, ID, \\ United States, ${ }^{3}$ Zoology Department, College of Science, King Saud University, Riyadh, Saudi Arabia, ${ }^{4}$ Department \\ of Marine Organism Taxonomy \& Phylogeny, Institute of Oceanology, Chinese Academy of Sciences, Qingdao, China, \\ ${ }^{5}$ Institute of Evolution and Marine Biodiversity, and College of Fisheries, Ocean University of China (OUC), Qingdao, China, \\ ${ }^{6}$ Laboratory for Marine Biology and Biotechnology, Qingdao National Laboratory for Marine Science and Technology, \\ Qingdao, China
}

Two oxytrichid ciliates collected from China, Oxytricha lithofera Foissner, 2016 and Rubrioxytricha haematoplasma (Blatterer and Foissner, 1990) Berger, 1999 were investigated based on living observations, protargol preparations, and molecular analyses. The Chinese population of $O$. lithofera shares highly distinctive features with the type population, e.g., lithosomes, abutting macronuclear nodules, straight undulating membranes, and long dorsal bristles. The morphology and morphogenesis of our new isolate of $R$. haematoplasma corresponds well with the type population. The 18S rRNA gene sequences of both species were obtained, and the molecular phylogeny of the genera Oxytricha Bory de Saint-Vincent in Lamouroux et al., 1824 and Rubrioxytricha Berger, 1999 was analyzed. In addition, we found that the Guangzhou population of $R$. haematoplasma described by Chen et al. (2015) can be distinguished from the type population and our isolate by the reddish-brown cortical granules (vs. lemon yellowish to greenish) and mitochondria-like granules present (vs. absent), as well as the slightly red cytoplasm (vs. slightly orange) and the marine or brackish water habitat (vs. freshwater). In addition, a 20-bp divergence in their 18S rRNA gene sequences indicates that they are not conspecific. Thus, we establish a new species, Rubrioxytricha guangzhouensis, for R. haematoplasma sensu Chen et al. (2015).

Keywords: hypotrich, morphology, morphogenesis, Oxytricha, phylogeny

\section{INTRODUCTION}

The family Oxytrichidae Ehrenberg, 1830, including more than 200 valid species, is one of the most morphologically and morphogenetically diverse hypotrichid ciliate groups (Berger, 1999, 2008; Foissner et al., 2002; Shao et al., 2011; Foissner, 2016; Hu et al., 2019; Kim et al., 2019; Dong et al., 2020; Wang et al., 2020a). The genus Oxytricha Bory de Saint-Vincent in Lamouroux et al., 1824, the type and time-honored genus of the family Oxytrichidae, comprises almost 40 nominal species isolated from various 
habitats worldwide and has been a melting pot for flexible 18cirri hypotrichs with caudal cirri for over one century (Berger, 1999; Shao et al., 2011, 2014; Weisse et al., 2013; Foissner, 2016; Kim and Min, 2019). Even though many studies have been carried out to delimit the genus more clearly (Berger, 1999; Shao et al., 2011, 2015; Foissner, 2016), it is still a polyphyletic genus with species irregularly distributed across the molecular tree (Schmidt et al., 2007; Paiva et al., 2009; Shao et al., 2014). The incongruence between morphology and molecular information suggests that this taxon is a genus with high genetic divergence (Berger, 1999; Foissner, 2016). Oxytricha lithofera, a highly distinctive species with a combination of features absent in any other described congeners (s. l.), was originally described by Foissner (2016) based on a population collected from moss on stones and soil from an old coral cave in the Golfete de Cuare del Indio, Venezuela. Here, we provide not only a description of the first Chinese population of $O$. lithofera but also the first analysis of the $18 \mathrm{~S}$ rRNA gene sequence for this species.

In a revision of oxytrichids, Berger (1999) transferred two Oxytricha species, viz., Oxytricha haematoplasma Blatterer and Foissner, 1990 and Oxytricha ferruginea Stein, 1859, to the newly established genus Rubrioxytricha Berger, 1999, with the former as the type species. Rubrioxytricha was mainly characterized by the homogeneously colored cytoplasm (slightly orange to reddish in $R$. haematoplasma and rusty brown in R. ferruginea), the presence of one or two caudal cirri, and four to five dorsal kineties. Three more Rubrioxytricha species have since been reported, namely $R$. indica Naqvi et al., 2006, $R$. tsinlingensis Chen et al., 2017, and R. guamensis Kumar et al., 2018 (Naqvi et al., 2006; Chen et al., 2017; Kumar et al., 2018). Recently, Chen et al. (2015) reported a brackish/marine population collected from Guangzhou, China, under the name R. haematoplasma. Herein, we describe a freshwater population of $R$. haematoplasma based on a detailed investigation of morphology and morphogenesis. A comprehensive comparison between $R$. haematoplasma populations as well as congeners is provided, and a new species is established. Updated phylogenetic analyses based on 18S rRNA gene sequences were also performed, and the non-monophyly of the genera Oxytricha and Rubrioxytricha are discussed.

\section{MATERIALS AND METHODS}

\section{Sample Collection, Observation, and Terminology}

A brackish water sample containing Oxytricha lithofera was collected from a sandy beach near Zhuhai Fishing Girl Statue $\left(22^{\circ} 15^{\prime} 41^{\prime \prime} \mathrm{N} ; 113^{\circ} 35^{\prime} 16^{\prime \prime} \mathrm{E}\right.$; Figures 1A,B) in Zhuhai, southern China, on 26 May 2014, when the water temperature was about $21^{\circ} \mathrm{C}$ and the salinity was about $3 \%$. The sample was maintained at about $22^{\circ} \mathrm{C}$ in Petri dishes with rice grains to enrich bacteria as a food source for the ciliates. Oxytricha lithofera was identified in this sample on 6 June 2014, when the salinity of the sample reached 6\%, and the population collapsed over the next 3 days. Investigations for $O$. lithofera were made with specimens from raw cultures rather than from cloned individuals. However, O. lithofera is easily distinguished by its long dorsal bristles and no other Oxytricha-like morphotypes were present in the protargol preparations, indicating that our morphological and molecular studies deal with the same species.

Rubrioxytricha haematoplasma was collected on 8 and 11 April 2016 from a freshwater lake in Wuhan Botanical Garden, Chinese Academy of Sciences $\left(30^{\circ} 32^{\prime} 57^{\prime \prime} \mathrm{N} ; 114^{\circ} 25^{\prime} 51^{\prime \prime} \mathrm{E}\right.$; Figures $1 \mathrm{~A}, \mathbf{C}$ ), Wuhan, China, when the water temperature was about $21^{\circ} \mathrm{C}$. Sponge cubes, with the length about $10 \mathrm{~cm}$, submerged at a depth of about $1 \mathrm{~m}$ for about 2 weeks, were used as artificial substrates to allow colonization by ciliates. Samples were collected according to Luo et al. (2018). Cells were selected and cultivated in Petri dishes at about $22^{\circ} \mathrm{C}$ with Volvic mineral water and rice grains. Although attempts to establish clonal cultures were unsuccessful, no other hypotrichid morphotypes were present in the protargol preparations, indicating that our morphological, morphogenetic, and molecular studies deal with the same species.

Live cells were isolated with micropipettes and then observed and measured with bright field and differential interference contrast microscopy at 40-1,000 $\times$ magnification using a Zeiss Axioplan 2 imaging microscope equipped with a Zeiss AxioCam HRc camera. The protargol staining method of Wilbert (1975) was used to reveal the nuclear apparatus and the ciliature. Counts, measurements, and photographs for protargol-stained specimens were made at a magnification of 1,000 $\times$ using an Olympus BX53 compound microscope (Tokyo, Japan) equipped with a Pixelink M5DC-SE-CYL camera (Ottawa, Canada). Drawings were made at a magnification of $1,000 \times$ or $1,250 \times$ with the aid of a drawing attachment or photomicrographs as templates. In the drawings of the morphogenetic stages, parental structures are shown as outlines, whereas new ones are shaded in black. Terminology is according to Berger (1999) and Foissner (2016).

\section{DNA Extraction and Gene Sequencing}

One to four randomly isolated cells were washed five times with filtered $(0.22 \mu \mathrm{m})$ habitat water or Volvic mineral water and then transferred to a $1.5-\mathrm{ml}$ microfuge tube as described by Zhang et al. (2020). Total genomic DNA was extracted using the DNeasy Blood and Tissue Kit (Qiagen, Hilden, Germany) according to the manufacturer's instructions with modification according to Lu et al. (2018). The 18S rRNA gene was amplified using the primers 18S-F (5'-AACCTGGTTGATCCTGCCAGT$\left.3^{\prime}\right)$ and 18S-R (5'-TGATCCTTCTGCAGGTTCACCTAC-3') (Medlin et al., 1988). Cycling parameters of touchdown PCR were as follows: one cycle of initial denaturation at $94^{\circ} \mathrm{C}$ for $5 \mathrm{~min}$, followed by 18 cycles of amplification $\left(94^{\circ} \mathrm{C}, 30 \mathrm{~s}\right.$; $66-49^{\circ} \mathrm{C}$ touch down, $\left.40 \mathrm{~s} ; 72^{\circ} \mathrm{C}, 2 \mathrm{~min}\right)$ and another 18 cycles $\left(94^{\circ} \mathrm{C}, 30 \mathrm{~s} ; 48^{\circ} \mathrm{C}, 40 \mathrm{~s} ; 72^{\circ} \mathrm{C}, 2 \mathrm{~min}\right)$, with a final extension of $72^{\circ} \mathrm{C}$ for $7 \mathrm{~min}$. The purified PCR product of $O$. lithofera of the appropriate size was inserted into the pEASY-T1 Cloning Vector (pEASY-T1 Cloning Kit, TransGen Biotech, Beijing, China) and sequenced using primers M13F (5'-CGCCAGGGTTTTCCCAGTCACGAC-3') and M13R (5'-AGCGGATAACAATTTCACACAGGA- $3^{\prime}$ ) and two internal primers at Sunny Biotechnology (Shanghai, China) (Zhang et al., 2019). For $R$. haematoplasma, cloning and sequencing in both directions were performed at Icongene 


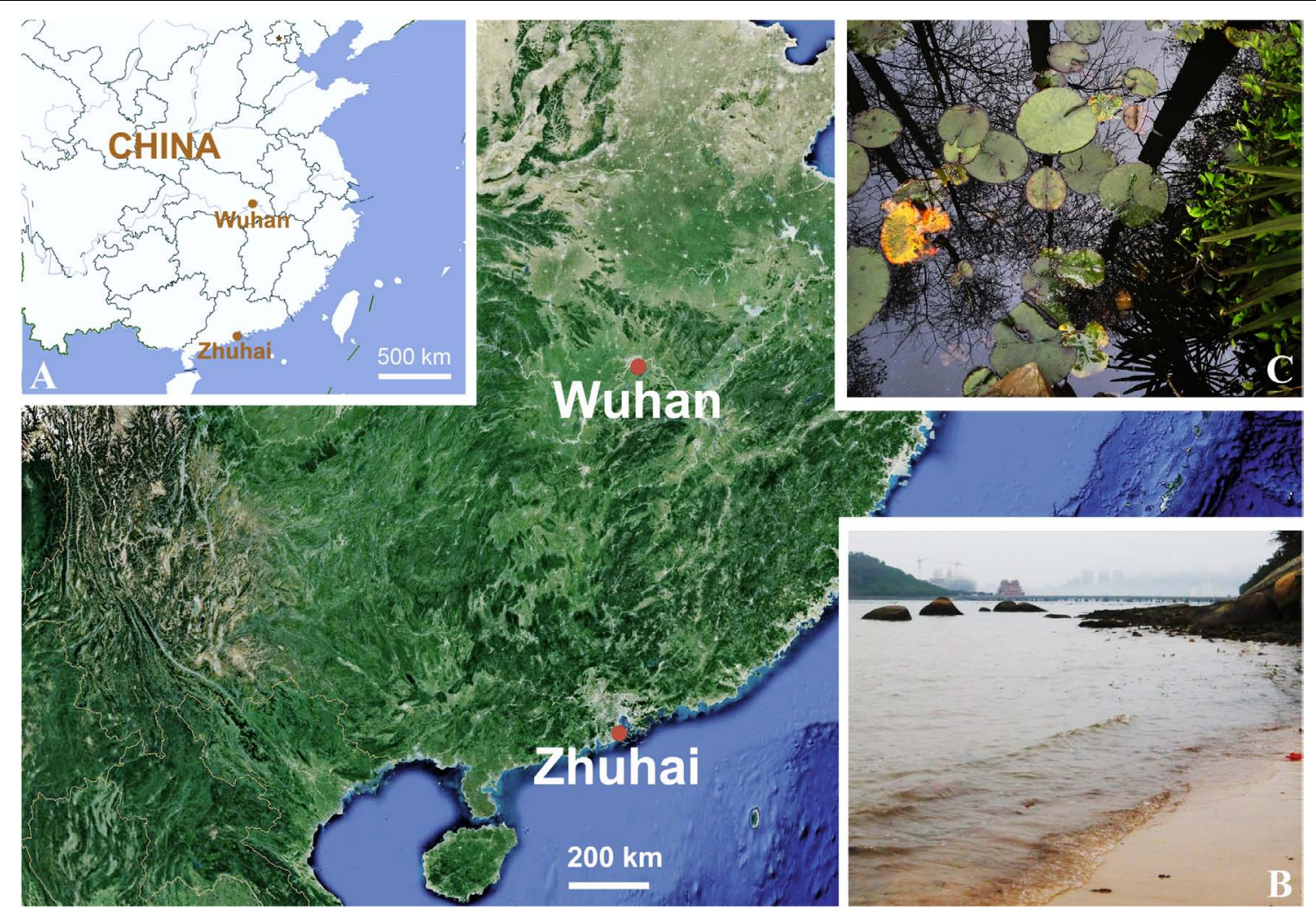

FIGURE 1 | (A-C) Locations and photographs of the sampling sites. (A) Locations of the sampling sites, marked with red dots. (B) Sandy beach near Zhuhai Fishing Girl Statue (22 $\left.15^{\prime} 41^{\prime \prime} \mathrm{N} ; 113^{\circ} 35^{\prime} 16^{\prime \prime} \mathrm{E}\right)$. (C) Freshwater pond in Wuhan Botanical Garden, Chinese Academy of Sciences $\left(30^{\circ} 32^{\prime} 57^{\prime \prime} \mathrm{N}\right.$; $\left.114^{\circ} 25^{\prime} 51^{\prime \prime} \mathrm{E}\right)$.

(Wuhan, China) using primers M13F and M13R and four internal primers E528F (5'-CGGTAATTCCAGCTCC-3' $)$, E1146F (5'-TGCATGGCCGTTCTTAG-3'), RevD (5'-GGA GCTGGAATTACCG-3'), and RevE (5'-CTAAGAACGG CCATGC-3'). Contigs were assembled using Seqman V. 7.1.0 (DNAStar).

\section{Phylogenetic Analyses}

The 18S rRNA gene sequences of 70 hypotrichids and four oligotrichous ciliates, i.e., Strombidinopsis acuminate (FJ790209), Strombidium apolatum (DQ662848), Novistrombidium orientale (FJ422988), and Parastrombidinopsis minima (DQ393786), selected as outgroup taxa, were downloaded from the National Center for Biotechnology Information (NCBI) Database ${ }^{1}$. The following stylonychines were selected: Gastrostyla steinii (AF508758), Histriculus histrio (FM209294), Laurentiella strenua (JX893368), Onychodromus grandis (AJ310486), Paraparentocirrus sibillinensis (KF184655), Parentocirrus sp. (KR063273), Pattersoniella vitiphila (JX885704), Pleurotricha lanceolata (AF508768), Rigidohymena candens (KC414885), Steinia sphagnicola (JX946276), Sterkiella cavicola (GU942565), Sterkiella histriomuscorum (FJ545743), Sterkiella nova (AF508771), Stylonychia ammermanni (FM209295), Stylonychia lemnae (AF508773), Stylonychia mytilus (AF508774), Stylonychia

${ }^{1}$ https://www.ncbi.nlm.nih.gov/ notophora (FM209297), Styxophrya quadricornuta (X53485), Tetmemena bifaria (FM209296), and Tetmemena pustulata (AF508775). The sequence alignment was performed on the GUIDANCE web server ${ }^{2}$ with the MUSCLE algorithm (Sela et al., 2015). The MUSCLE alignment score is 0.997502 and unreliable columns below confidence score 0.987 (97\% of columns remain) were removed. The program BioEdit 7.2.5 (Hall, 1999) was used to remove the primers from the aligned sequences. The final alignment used for phylogenetic tree construction included 76 taxa with 1,703 positions. The GTR model of nucleotide substitution was selected as the best model by the program MrModeltest v.2.2 (Nylander, 2004) and was then used for Bayesian inference (BI) analysis. BI analysis was performed with MrBayes 3.2.7 on XSEDE (Ronquist et al., 2012) on the CIPRES Science Gateway ${ }^{3}$, with 2,000,000 generations, a sampling frequency of every 100th generation, and a burn-in of 5,000 trees. The remaining trees were used to calculate the posterior probabilities with a majority rule consensus. Maximum likelihood (ML) analysis was carried out using RAxML-HPC2 on XSEDE v 8.2.12 in CIPRES Science Gateway with the GTRGAMMA model (Miller et al., 2010; Stamatakis, 2014). The reliability of the internal branches was assessed by a non-parametric bootstrap method using 1,000 resamplings.

\footnotetext{
${ }^{2}$ http://guidance.tau.ac.il/
}

${ }^{3}$ https://www.phylo.org 
Tree topologies were displayed with SeaView v 4.6.1 (Gouy et al., 2010) and MEGA 7.0.26 (Tamura et al., 2013). The systematic classification follows Lynn (2008).

The statistical probability of the monophyletic hypothesis of the genus Rubrioxytricha was evaluated using AU tests (Shimodaira, 2002) in the CONSEL package (Shimodaira and Hasegawa, 2001).

\section{RESULTS}

\section{ZooBank Registration}

Present work: urn:lsid:zoobank.org:pub:C09DE513-8C3A-422C8953-2AFBF5581313.

\section{Oxytricha lithofera Foissner, 2016 Deposition of Voucher Specimens}

Two voucher slides with protargol-stained specimens were deposited in the Laboratory of Protozoology, OUC, China, with registration numbers LXT2014052601-01 02.

\section{Morphology Based on the Zhuhai Population (Figures 2A-P, 3A-J and Table 1)}

Cells $80-115 \times 25-40 \mu \mathrm{m}$ in vivo, ellipsoid in outline with both ends rounded, left margin more or less convex, right margin usually more or less straight (Figures 2A,B, 3A-E). Dorsoventrally flattened 2-3:1. Body flexible, not contractile. One contractile vacuole slightly above mid-body at left cell margin, about $8 \mu \mathrm{m}$ in diameter in diastole (Figures $\mathbf{2 A}$,

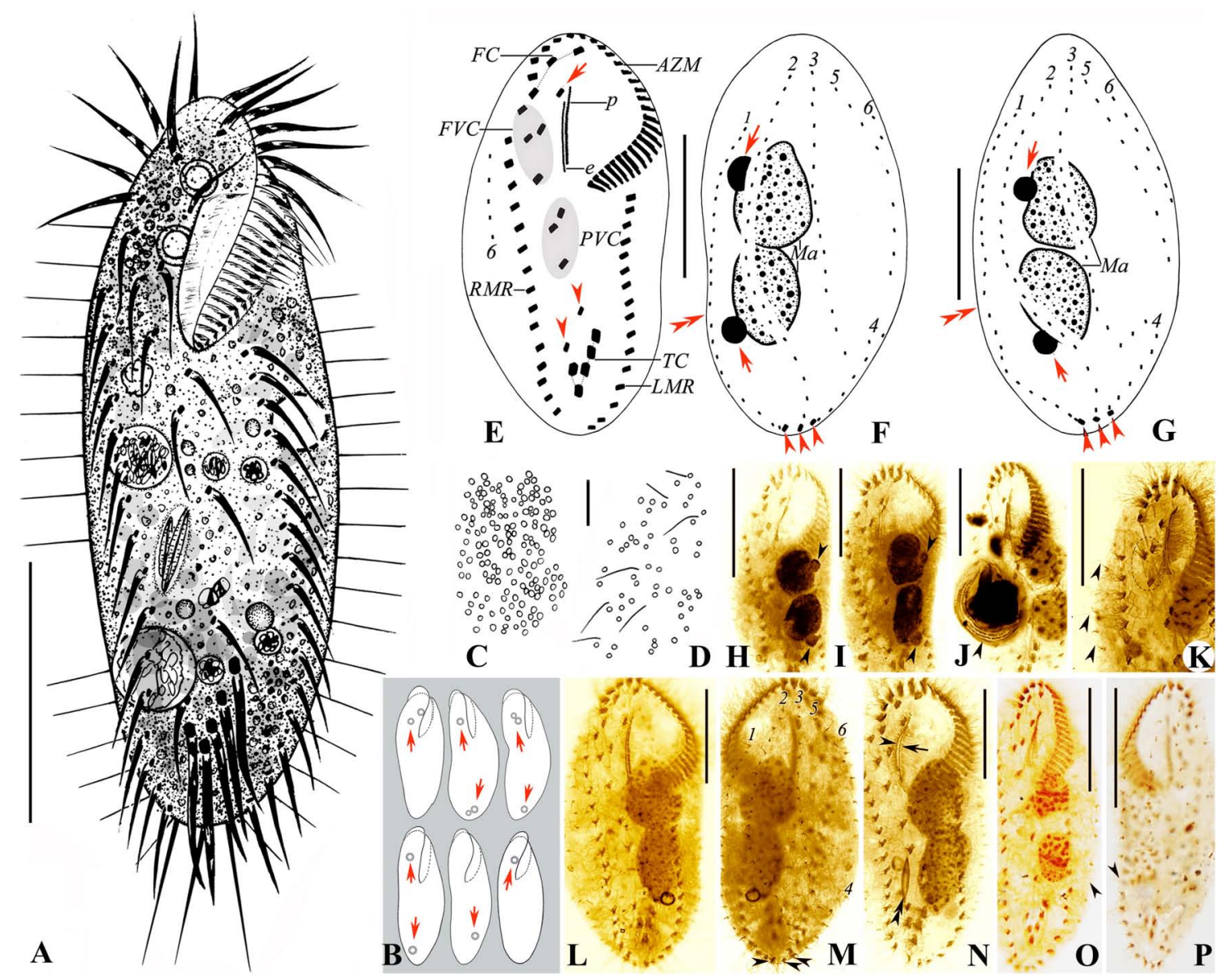

FIGURE 2 | (A-P) Morphology and ciliature of the Zhuhai population of Oxytricha lithofera from life (A-D) and after protargol impregnation (E-P). (A) Ventral view of a representative individual. (B) Ventral views, showing body shape and lithosomes (arrows). (C,D) Distribution of cortical granules on the ventral (C) and dorsal (D) side. (E-G) Ventral (E) and dorsal (F,G) views of representative specimens, showing ciliature and nuclear apparatus; arrowheads in (E) mark pretransverse ventral

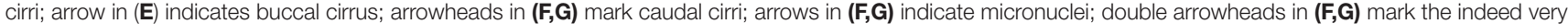
indistinct gap in dorsal kinety 1. (H,I) Ventral views showing the abutting macronuclear nodules and the large micronuclei (arrowheads) attached to the macronuclear nodules. (J) Ventral view, showing a specimen with an ingested ciliate (arrowhead). (K) Ventral view of a specimen with three frontoventral cirri; arrowheads indicate the long dorsal bristles of dorsal kinety 6. (L,M) Ventral (L) and dorsal (M) views of a representative specimen, the same one as (E,F); arrowheads mark caudal cirri. (N) Ventral view, showing ciliature, the abutting macronuclear nodules, and an ingested diatom (double arrowheads); arrowhead indicates paroral membrane; arrow marks endoral membrane. (O,P) Show the slightly conspicuous one-bristle-wide gap in dorsal kinety 1 . AZM, adoral zone of membranelles; e, endoral membrane; FC, frontal cirri; FVC, frontoventral cirri; LMR, left marginal row; Ma, macronuclear nodules; p, paroral membrane; PVC, postoral ventral cirri; RMR, right marginal row; TC, transverse cirri; 1-6, dorsal kineties. Scale bars $=30 \mu \mathrm{m}(\mathbf{A}, \mathbf{E}-\mathbf{P})$ and $10 \mu \mathrm{m}$ (C,D) 


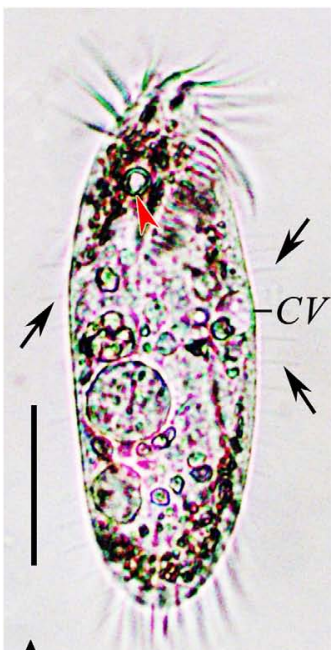

A

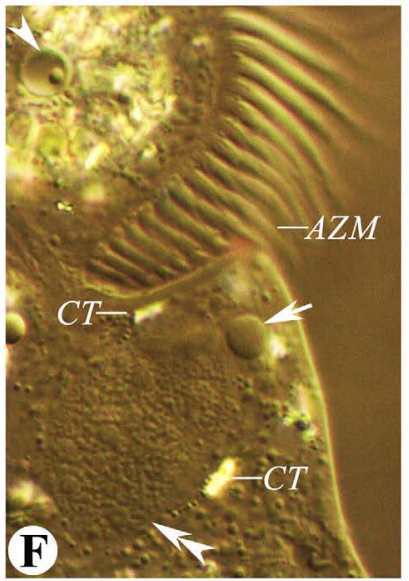

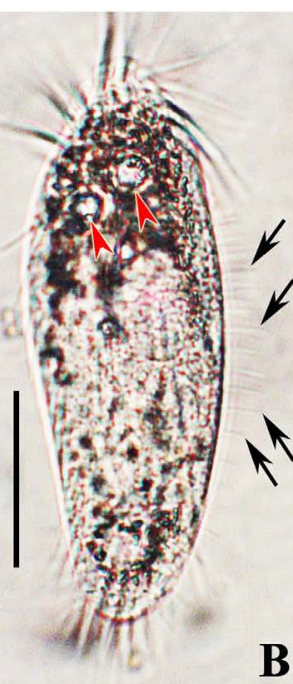

B

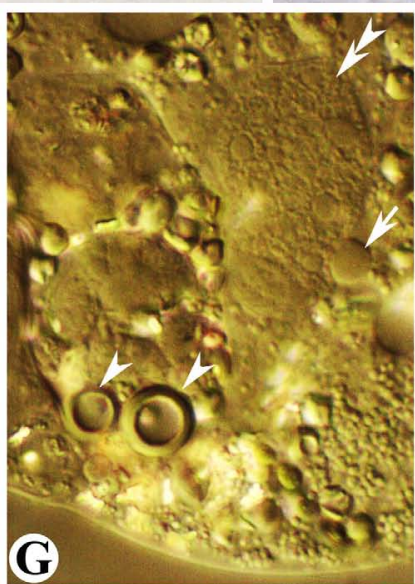

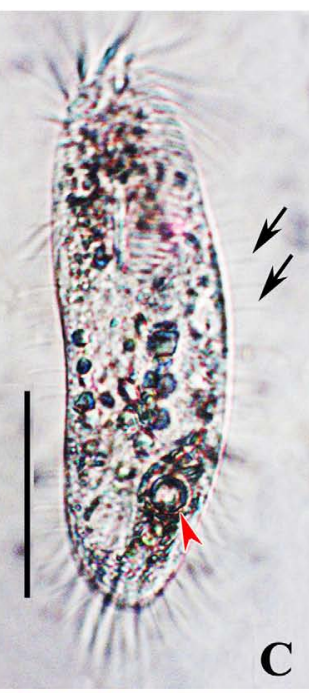
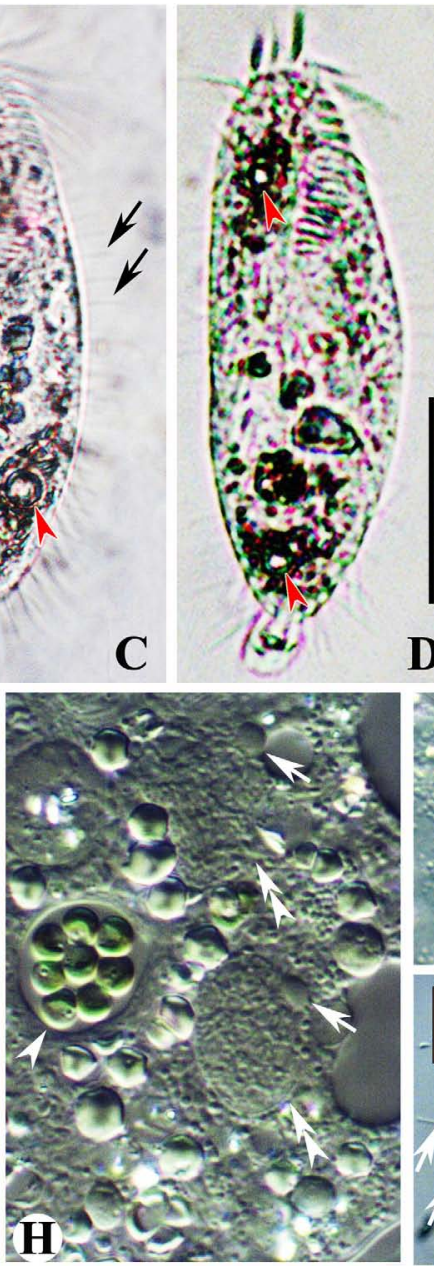

D
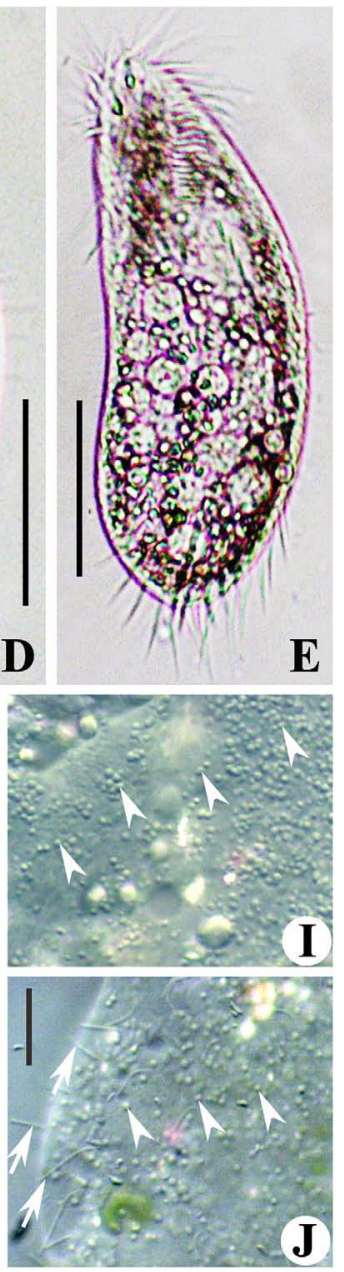

FIGURE 3 | (A-J) Morphology of the Zhuhai population of Oxytricha lithofera from life (A-E, bright field; F-J, differential interference contrast). (A-E) Ventral views of representative individuals, showing body shape, flexibility, contractile vacuole, lithosomes (arrowheads), and the long dorsal bristles (arrows). (F,G) Anterior (F) and posterior (G) part of the same specimen, showing three lithosomes (arrowheads), two macronuclear nodules (double arrowheads), two large-sized micronuclei (arrows), and crystals. (H) Ventral view, showing macronuclear nodules (double arrowheads), micronuclei (arrows), food vacuole (arrowhead), and inclusions. (I,J) Mitochondria-like cortical granules (arrowheads) on ventral (I) and dorsal (J) side; arrows in (J) indicate the long dorsal bristles. AZM, adoral zone of membranelles; CT, crystals; CV, contractile vacuole. Scale bars = $30 \mu \mathrm{m}$ (A-E) and $10 \mu \mathrm{m}$ (J)

3A). Mitochondria-like cortical granules present, globular, about $1.0-1.5 \mu \mathrm{m}$ across, irregularly distributed on the ventral and dorsal sides (Figures 2C,D, 3I,J). Cytoplasm colorless, usually packed with numerous irregularly shaped shining granules (3$5 \mu \mathrm{m}$-sized), minute crystals (Figure 3F), and some food vacuoles, containing ciliates (Figure 2J, arrowhead), diatoms (Figure $\mathbf{2 N}$, double arrowheads), and green algae (Figure $\mathbf{3 H}$, arrowhead). One, two, or three ring-shaped lithosomes, 4-7 $\mu \mathrm{m}$ in diameter, with wall $1.0-1.5 \mu \mathrm{m}$ thick, located subapically and/or subterminally (Figures 2B, 3A-D,F,G). Two abutting macronuclear nodules, positioned in mid-body and left of midline, broadly to elongate ellipsoid, on average $21 \times 15 \mu \mathrm{m}$ in protargol preparations, with anterior one extending slightly anterior to the buccal vertex (Figures 2F-I). Consistently two globular micronuclei about $4 \mu \mathrm{m}$ across, each one attached to one macronuclear nodule, usually on the left side (Figures 2F-I,
3F-H). Locomotion by moderately fast crawling on the substrate, occasionally swimming.

Adoral zone extending 35-51\% of body length (average 42\%) in protargol preparations, composed of 21-29 membranelles (Table 1), with cilia 13-15 $\mu \mathrm{m}$ long in vivo. Paroral and endoral membrane almost equal in length, more or less straight, optically side by side, or superimposed, with paroral extending slightly more anteriorly than endoral (Figures 2 E,L,N).

Ventral cirral pattern as shown in Figures 2E,K,L,N. Three frontal cirri with the right one located behind the distal end of the adoral zone, easily misinterpreted as an adoral membranelle. One buccal cirrus, located anterior to the endoral membrane and right of the anterior end of the paroral membrane. Usually four frontoventral cirri (only one out of 20 cells observed with three, Figure 2K) arranged in V shape, three of them (IV/3, VI/3, VI/4) arranged in a line, cirrus III/2 slightly above the level of cirrus 
TABLE 1 | Morphometric data of the Chinese populations of Oxytricha lithofera $(O /)$ and Rubrioxytricha haematoplasma (Rh) based on protargol-stained specimens.

\begin{tabular}{|c|c|c|c|c|c|c|c|c|}
\hline Character & Species & Min & Max & Mean & $M$ & SD & CV & $n$ \\
\hline \multirow[t]{2}{*}{ Body, length ( $\mu \mathrm{m})$} & $\mathrm{Ol}$ & 60 & 105 & 88.6 & 90 & 11.5 & 12.9 & 19 \\
\hline & $R h$ & 122 & 175 & 151.1 & 154 & 15 & 10 & 17 \\
\hline \multirow[t]{2}{*}{ Body, width ( $\mu \mathrm{m})$} & $\mathrm{Ol}$ & 29 & 51 & 41.7 & 42 & 6.2 & 14.9 & 19 \\
\hline & $R h$ & 45 & 74 & 62.1 & 63 & 7.9 & 12.7 & 17 \\
\hline \multirow[t]{2}{*}{ Body width: length, percentage } & $\mathrm{Ol}$ & 40 & 60 & 47.3 & 45.7 & 5.4 & 11.5 & 19 \\
\hline & $R h$ & 31 & 47 & 41.2 & 41.4 & 4 & 9.8 & 17 \\
\hline \multirow[t]{2}{*}{ Adoral zone length ( $\mu \mathrm{m})$} & $\mathrm{Ol}$ & 27 & 46 & 37 & 37 & 5.7 & 15.3 & 19 \\
\hline & $R h$ & 47 & 62 & 53.4 & 53 & 3.7 & 7 & 17 \\
\hline \multirow[t]{2}{*}{ Adoral zone length: body length, percentage } & $\mathrm{Ol}$ & 35 & 51 & 41.8 & 41 & 4.4 & 10.4 & 19 \\
\hline & $R h$ & 29 & 41 & 35.6 & 35.1 & 2.8 & 8 & 17 \\
\hline \multirow[t]{2}{*}{ Adoral membranelles, number } & $\mathrm{Ol}$ & 21 & 29 & 25.8 & 27 & 2.7 & 10.5 & 19 \\
\hline & $R h$ & 34 & 41 & 37.6 & 38 & 2 & 5.4 & 17 \\
\hline \multirow[t]{2}{*}{ Frontal cirri, number } & $\mathrm{Ol}$ & 3 & 3 & 3 & 3 & 0 & 0 & 19 \\
\hline & $R h$ & 3 & 3 & 3 & 3 & 0 & 0 & 17 \\
\hline \multirow[t]{2}{*}{ Buccal cirrus, number } & $\mathrm{Ol}$ & 1 & 1 & 1 & 1 & 0 & 0 & 19 \\
\hline & $R h$ & 1 & 1 & 1 & 1 & 0 & 0 & 17 \\
\hline \multirow[t]{2}{*}{ Frontoventral cirri, number } & $\mathrm{Ol}$ & 3 & 4 & 4 & 4 & 0.2 & 5.7 & 20 \\
\hline & $R h$ & 4 & 4 & 4 & 4 & 0 & 0 & 17 \\
\hline \multirow[t]{2}{*}{ Postoral ventral cirri, number } & $\mathrm{Ol}$ & 3 & 3 & 3 & 3 & 0 & 0 & 19 \\
\hline & $R h$ & 3 & 3 & 3 & 3 & 0 & 0 & 13 \\
\hline \multirow[t]{2}{*}{ Pretransverse ventral cirri, number } & $\mathrm{Ol}$ & 2 & 2 & 2 & 2 & 0 & 0 & 19 \\
\hline & $R h$ & 2 & 2 & 2 & 2 & 0 & 0 & 16 \\
\hline \multirow[t]{2}{*}{ Transverse cirri, number } & $\mathrm{Ol}$ & 5 & 5 & 5 & 5 & 0 & 0 & 19 \\
\hline & $R h$ & 4 & 6 & 5 & 5 & 0.4 & 7.1 & 17 \\
\hline \multirow[t]{2}{*}{ Left marginal cirri, number } & $\mathrm{Ol}$ & 14 & 18 & 15.4 & 15 & 1 & 6.6 & 19 \\
\hline & $R h$ & 29 & 40 & 35.2 & 36 & 2.7 & 7.7 & 17 \\
\hline \multirow[t]{2}{*}{ Right marginal cirri, number } & $\mathrm{Ol}$ & 13 & 16 & 14.9 & 15 & 0.8 & 5.4 & 19 \\
\hline & $R h$ & 29 & 40 & 34.9 & 35 & 3 & 8.5 & 17 \\
\hline \multirow[t]{2}{*}{ Caudal cirri, number } & $\mathrm{Ol}$ & 3 & 3 & 3 & 3 & 0 & 0 & 19 \\
\hline & $R h$ & 1 & 1 & 1 & 1 & 0 & 0 & 17 \\
\hline \multirow[t]{2}{*}{ Dorsal kineties, number } & $\mathrm{Ol}$ & 6 & 6 & 6 & 6 & 0 & 0 & 18 \\
\hline & $R h$ & 4 & 4 & 4 & 4 & 0 & 0 & 17 \\
\hline \multirow[t]{2}{*}{ Dikinetids in dorsal kinety 1 , number } & $\mathrm{Ol}$ & 13 & 26 & 21.7 & 23 & 3.9 & 18.2 & 18 \\
\hline & $R h$ & 18 & 27 & 23.6 & 24 & 2.3 & 9.9 & 17 \\
\hline \multirow[t]{2}{*}{ Dikinetids in dorsal kinety 2 , number } & $\mathrm{Ol}$ & 11 & 25 & 18.6 & 20 & 3.7 & 19.7 & 17 \\
\hline & $R h$ & 19 & 30 & 22.8 & 23 & 2.7 & 11.6 & 17 \\
\hline Dikinetids in dorsal kinety 3 , number & $\mathrm{Ol}$ & 10 & 21 & 14.4 & 13.5 & 3.2 & 22 & 16 \\
\hline & $R h$ & 19 & 28 & 22.6 & 23 & 2.4 & 10.6 & 17 \\
\hline Dikinetids in dorsal kinety 4 , number & $\mathrm{Ol}$ & 3 & 8 & 5.4 & 5 & 1.5 & 27.8 & 18 \\
\hline & $R h$ & 14 & 26 & 19.1 & 19 & 3.1 & 16.1 & 16 \\
\hline Dikinetids in dorsal kinety 5 , number & $\mathrm{Ol}$ & 5 & 18 & 9.1 & 9 & 2.8 & 30.9 & 18 \\
\hline Dikinetids in dorsal kinety 6 , number & $\mathrm{Ol}$ & 4 & 9 & 6.4 & 6 & 1.5 & 22.9 & 17 \\
\hline Macronuclear nodules, number & $\mathrm{Ol}$ & 2 & 2 & 2 & 2 & 0 & 0 & 19 \\
\hline & $R h$ & 2 & 2 & 2 & 2 & 0 & 0 & 15 \\
\hline Anterior macronuclear nodule, length ( $\mu \mathrm{m})$ & $\mathrm{Ol}$ & 14 & 26 & 21.2 & 22.5 & 4 & 19.1 & 18 \\
\hline & $R h$ & 18 & 33 & 24.8 & 25 & 4.8 & 19.4 & 15 \\
\hline Anterior macronuclear nodule, width ( $\mu \mathrm{m})$ & Ol & 9 & 20 & 15 & 15.5 & 3.5 & 23.5 & 18 \\
\hline & $R h$ & 8 & 13 & 10.1 & 10 & 1.8 & 17.4 & 15 \\
\hline Posterior macronuclear nodule, length $(\mu \mathrm{m})$ & Ol & 14 & 30 & 22.2 & 22.5 & 4.6 & 20.8 & 18 \\
\hline & $R h$ & 19 & 30 & 25 & 25 & 3.4 & 13.8 & 15 \\
\hline Posterior macronuclear nodule, width $(\mu \mathrm{m})$ & $\mathrm{Ol}$ & 10 & 18 & 13.4 & 14 & 2.6 & 19.6 & 18 \\
\hline & $R h$ & 7 & 12 & 9.7 & 10 & 1.7 & 17.3 & 15 \\
\hline
\end{tabular}


TABLE 1 | Continued

\begin{tabular}{|c|c|c|c|c|c|c|c|c|}
\hline Character & Species & Min & Max & Mean & $M$ & SD & CV & $n$ \\
\hline \multirow[t]{2}{*}{ Micronuclei, number } & $\mathrm{Ol}$ & 2 & 2 & 2 & 2 & 0 & 0 & 9 \\
\hline & $R h$ & 2 & 3 & 2.1 & 2 & 0.3 & 12.9 & 14 \\
\hline \multirow[t]{2}{*}{ Micronucleus, length ( $\mu \mathrm{m})$} & $\mathrm{Ol}$ & 3 & 5 & 4.1 & 4 & 0.5 & 13.2 & 11 \\
\hline & $R h$ & 5 & 8 & 6.5 & 6.5 & 0.7 & 11.5 & 28 \\
\hline \multirow[t]{2}{*}{ Micronucleus, width ( $\mu \mathrm{m})$} & Ol & 3 & 5 & 3.8 & 4 & 0.6 & 15.1 & 12 \\
\hline & $R h$ & 3 & 5 & 4.2 & 4 & 0.5 & 11.8 & 28 \\
\hline
\end{tabular}

Abbreviations: CV, coefficient of variation in\%; M, median; Max, maximum; Mean, arithmetic mean; Min, minimum; $n$, number of cells measured; SD, standard deviation.

VI/3. Three postoral ventral cirri arranged in a triangular pattern. Two pretransverse ventral cirri, with the posterior one almost at the same level as transverse cirrus III/1. Five enlarged transverse cirri, arranged in a check-mark shape, with cilia 18-20 $\mu \mathrm{m}$ long in vivo, conspicuously protruding beyond the posterior end of the cell (Figures 2A, 3A-E). Single marginal row on either body side, separated by a distinct gap, left one with 14-18 cirri, right one with 13-16 cirri, with cilia about $13 \mu \mathrm{m}$ in length.

Invariably six dorsal kineties (DK): DK1, the leftmost kinety, strongly shortened anteriorly, reaches the posterior end, with an indeed very indistinct gap in most specimens (Figures 2F,G, double arrowheads), only six out of 25 cells observed with a slightly conspicuous gap (Figures 2O,P, arrowhead); DK2 almost extending the entire body length; DK3 extends to the anterior body end and splits to form a short row of DK4 (on an average of five dikinetids) at the subterminal end, usually one or two dikinetids between DK3 and DK4; DK5 and DK6, the dorsomarginal kineties, shortened anteriorly, with DK5 reaching the mid-body, DK6 extends slightly above the midbody (Figures 2F,G,M). Bristles conspicuous in vivo, even at low magnification (Figures $\mathbf{3 A - C}, \mathbf{J}$, arrows), anterior bristles of DK1-3 about $5 \mu \mathrm{m}$ long, gradually increase to $9 \mu \mathrm{m}$ posteriorly; bristles of DK4 usually 8-9 $\mu \mathrm{m}$ long, bristles of DK5 and DK6 usually 5-7 $\mu \mathrm{m}$ long. Three long caudal cirri, with cilia 18-20 $\mu \mathrm{m}$ long, one each at end of DK1,2, and 4, optically positioned in gap between ends of marginal rows (Figures 2F,G,M).

\section{Rubrioxytricha haematoplasma (Blatterer and Foissner, 1990) Berger, 1999}

\section{Deposition of Voucher Specimens}

Voucher slides with protargol-stained specimens were deposited in the Laboratory of Protozoology, OUC, China, with registration numbers LXT2016040802-01 03 and LXT2016041102-01 02.

\section{Morphology Based on the Wuhan Population (Figures 4A-N and Table 1)}

Cells $125-160 \times 40-60 \mu \mathrm{m}$ in vivo. Body soft, flexible and not contractile. Body long ellipsoid in shape, both anterior and posterior ends rounded, some with broad ends, some with narrower ends, right and left margins more or less convex (Figures 4A,D,G-I). Dorsoventrally flattened about 2:1. Single contractile vacuole slightly behind the buccal vertex and ahead of the mid-body, about $45 \%$ of body length, at the left cell margin, approximately $12 \mu \mathrm{m}$ in diameter in diastole, two longitudinally oriented collecting canals present (Figures 4A,D,G-I). Cortical granules of single type, spherical, 0.8-1.0 $\mu \mathrm{m}$ across, lemon yellowish to greenish, arranged in lines or small groups then in long lines on both body sides (Figures 4B,C,J-L, slightly squeezed cells). Cytoplasm slightly orange (Figures 4J,L), usually packed with numerous irregularly shaped granules (2-6 $\mu \mathrm{m}$-sized) and food vacuoles, containing diatoms, sometimes rendering cells yellow-brown to slightly darkish at low magnification. Consistently two macronuclear nodules, positioned in the mid-body and more or less left of midline, with the anterior one almost at the level of the buccal vertex, each nodule elongate ellipsoidal in shape, on average $25 \times 10 \mu \mathrm{m}$ after protargol preparation. Usually two ellipsoidal micronuclei, 5-8 $\times 3-5 \mu \mathrm{m}$ in size, with one attached to or near each macronuclear nodule (Figures 4F,M,N). Locomotion by slowly crawling on the substrate, occasionally swimming with cells rotating around the longitudinal axis.

Adoral zone $29-41 \%$ of body length (average 36\%) in protargol preparations, composed of 34-41 membranelles (Table 1). Cilia of membranelles $18-20 \mu \mathrm{m}$ long in vivo, widest base about $10 \mu \mathrm{m}$. Undulating membranes in Australocirrus pattern (Kumar and Foissner, 2015), that is, paroral moderately to distinctly curved but not recurved distally, paroral extending slightly anteriorly to endoral and almost equal in length, both membranes optically intersecting at middle of paroral (Figures 4E,M).

Ventral cirral pattern as shown in Figures 4E,M. Three slightly enlarged frontal cirri continuous with frontoventral cirri arranged in a $\mathrm{V}$-shaped pattern, rightmost three (IV/3, VI/3, $\mathrm{VI} / 4$ ) almost arranged in a line, cirrus III/2 slightly ahead level of the posteriormost one (cirrus IV/3) and distant from cirrus VI/3. Single buccal cirrus, almost at the same level with the right frontal cirrus. Three postoral ventral cirri and two pretransverse ventral cirri. On average five slightly enlarged transverse cirri, with cilia 20-22 $\mu \mathrm{m}$ long, extending slightly behind the rear end of the cell, arranged in a check-mark shape, just behind the pretransverse ventral cirri. Single left and right marginal row, more or less confluent at the posterior end.

Invariably four dorsal kineties (DK): three bipolar ones (DK1-3) with about 23 dikinetids each, one slightly shortened dorsomarginal kinety (DK4) comprising about 19 dikinetids. Always one parental dorsal kinety fragment located between DK3 and DK4, with sparsely arranged monokinetids (Figures 4F,N, arrowheads). Dorsal bristles 3-4 $\mu \mathrm{m}$ long in vivo (Figure $4 \mathrm{~L}$, arrowheads). Single caudal cirrus located at the end of DK3 (Figures 4F,M, arrow). 


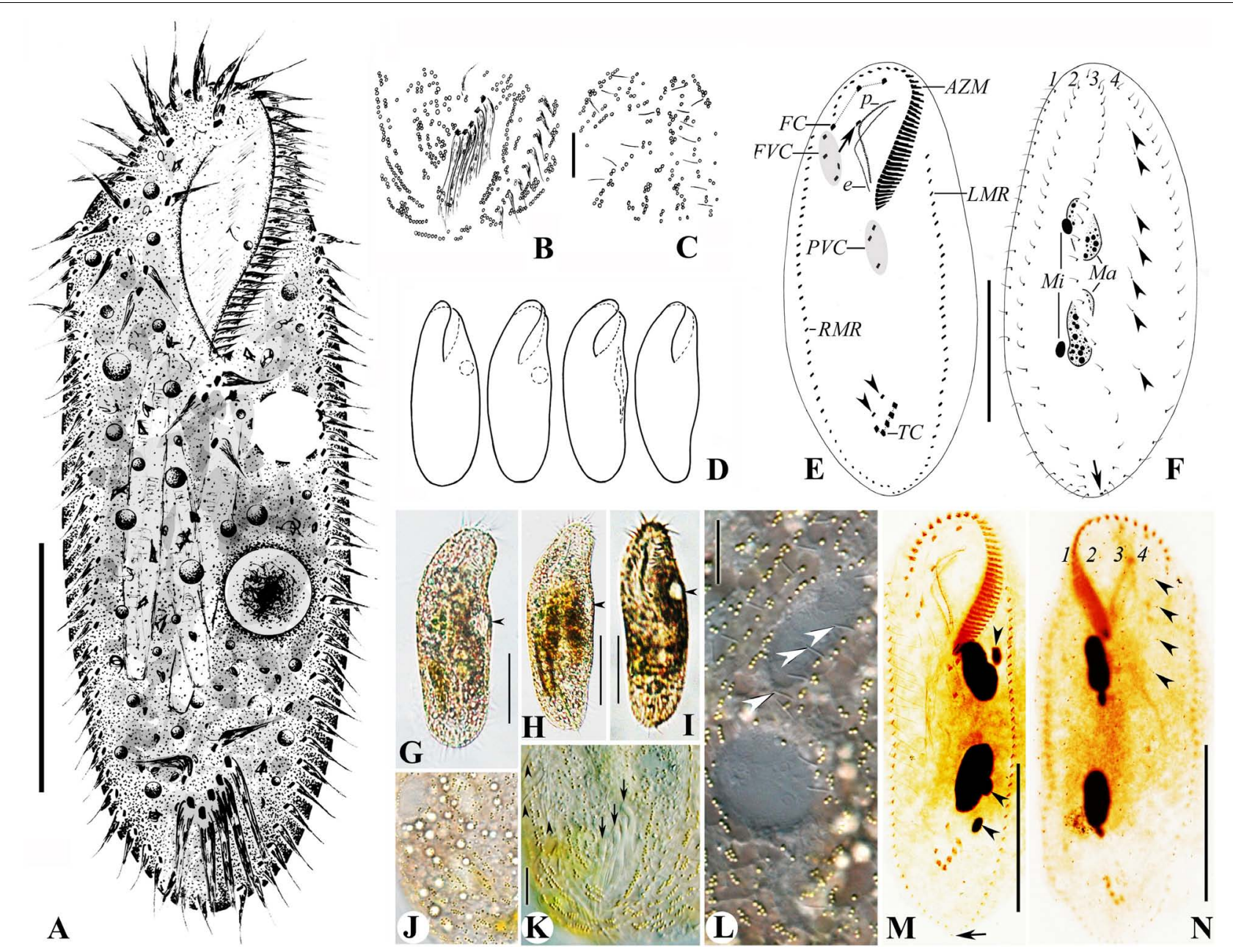

FIGURE 4 | (A-N) Morphology and ciliature of the Wuhan population of Rubrioxytricha haematoplasma from life (A-D; G-J, bright field; K,L, differential interference contrast) and after protargol impregnation (E,F,M,N). (A) Ventral view of a representative individual. (B,C) Distribution of cortical granules on the ventral (B) and dorsal (C) side. (D) Ventral views, showing body shape and contractile vacuole. (E,F) Ventral (E) and dorsal (F) views of a representative specimen, showing ciliature and nuclear apparatus; arrowheads in (E) mark pretransverse ventral cirri; arrow in (E) indicates buccal cirrus; arrowheads in (F) show parental dorsal bristles; arrow in (F) marks the single caudal cirrus at end of dorsal kinety 3. (G-I) Ventral view of representative individuals, showing body shape, flexibility, and contractile vacuole (arrowhead). (J) Dorsal view of a slightly squeezed cell, showing the color of cortical granules and cytoplasm. (K) Ventral view of the posterior part of a slightly squeezed cell, showing the distribution of cortical granules; arrowheads indicate right marginal cirri; arrows show the slightly enlarged transverse cirri. (L) Dorsal view of a slightly squeezed cell, showing the distribution of cortical granules on the dorsal side; arrowheads indicate dorsal bristles. (M,N) Ventral (M) and dorsal (N) views of representative specimens, showing ciliature and nuclear apparatus; arrowheads in (M) show micronuclei; arrow in (M) indicates the single caudal cirrus;

arrowheads in (N) mark parental dorsal bristles. AZM, adoral zone of membranelles; e, endoral membrane; FC, frontal cirri; FVC, frontoventral cirri; LMR, left marginal row; Ma, macronuclear nodules; Mi, micronuclei; $\mathrm{p}$, paroral membrane; PVC, postoral ventral cirri; RMR, right marginal row; TC, transverse cirri; 1-4, dorsal kineties. Scale bars = $50 \mu \mathrm{m}(\mathbf{A}, \mathbf{E}, \mathbf{F}, \mathbf{G}-\mathbf{I}, \mathbf{M}, \mathbf{N})$ and $10 \mu \mathrm{m}(\mathbf{B}, \mathbf{C}, \mathbf{K}, \mathbf{L})$.

\section{Morphogenesis (Figures 5A-H, 6A-H and Table 1)}

In a very early divider (Figures $\mathbf{5 A}, \mathbf{6 A}$ ), stomatogenesis commences with appearance of the oral primordium as groups of basal bodies between the buccal vortex and transverse cirri, including a large group just left to the postoral ventral cirri. At this stage, all parental cirri remain intact and do not contribute to the formation of the oral primordium. Somewhat later (Figures 5B, 6B), the anterior two postoral ventral cirri (IV/2, $\mathrm{V} / 4$ ) dedifferentiate and contribute to the oral primordium. In an early divider (Figures 5C, 6C), the posterior postoral ventral cirrus $(\mathrm{V} / 3)$ is no longer recognizable and the oral primordium gives rise to new adoral membranelles. Simultaneously, the parental undulating membranes dedifferentiate anteriorly to form the undulating membranes anlage (UMA) (Figure 5C, arrow) and the frontal-ventral-transverse cirral anlagen (FVTA) begin to form. In a middle divider (Figures 5E, 6D), two sets of FVTA are formed. Subsequently (Figures 5G, 6F), the UMA forms the new undulating membranes and gives rise to the left frontal cirrus. At the same time, the other streaks differentiate into new cirri in the pattern of 3:3:3:4:4 from left to right. The parental adoral zone, which is inherited by the proter, remains unchanged throughout the whole process (Figures 5C,E,G). 

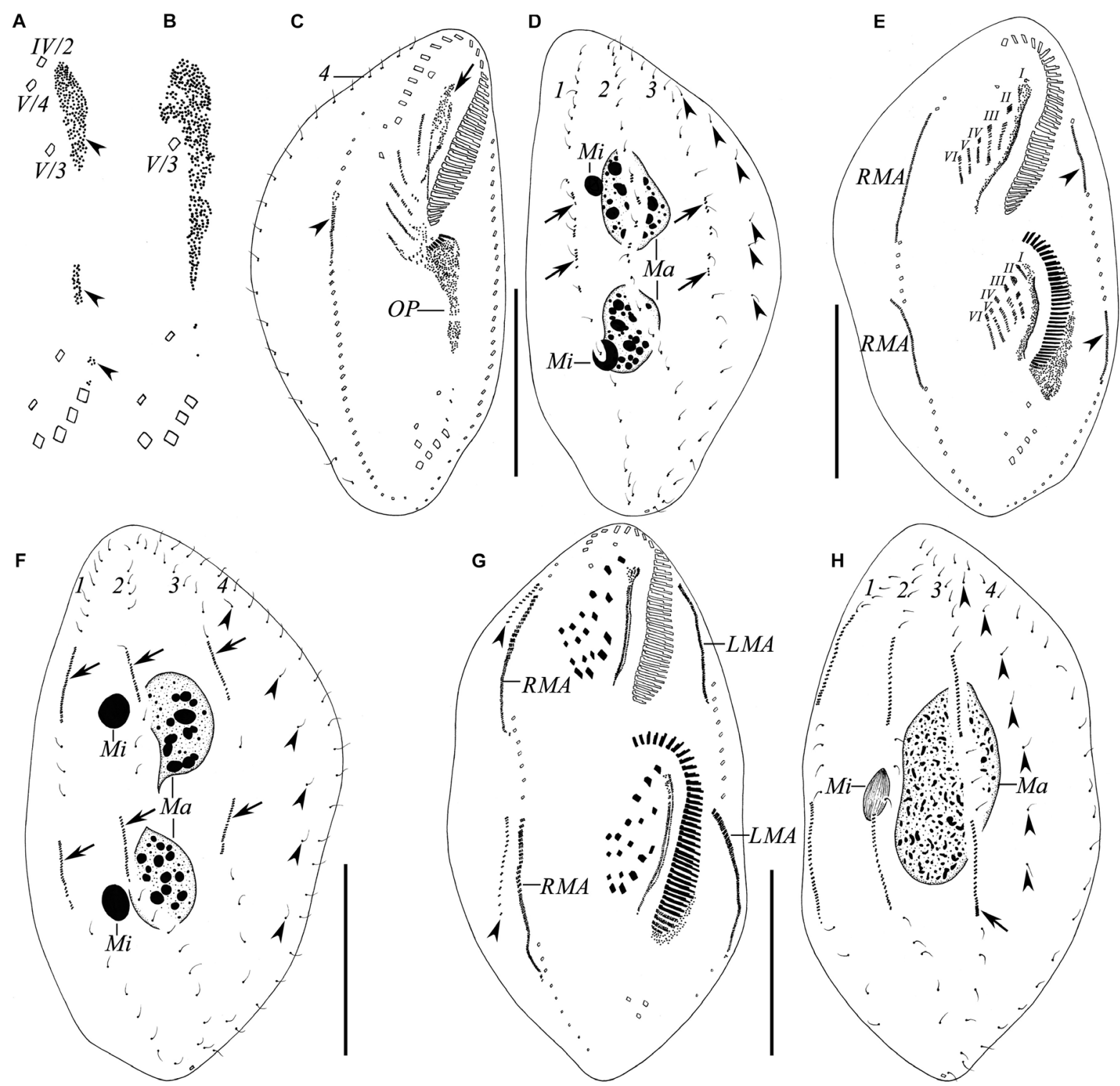

FIGURE 5 | (A-H) Ciliature of the Wuhan population of Rubrioxytricha haematoplasma during the ontogenetic process after protargol impregnation. (A,B) Ventral views of very early dividers, showing the formation of the oral primordium. (C,D) Ventral (C) and dorsal (D) views of an early divider, showing the formation of frontal-ventral-transverse cirral anlagen; arrow in (C) indicates undulating membranes anlage of proter (= anlage I) dedifferentiated from old structure; arrowhead in (C) marks right marginal anlage of proter; arrows in (D) show newly formed dorsal kinety anlagen; arrowheads in (D) indicate grandparental dorsal bristles. (E,F) Ventral (E) and dorsal (F) views of a middle divider, showing two sets of frontal-ventral-transverse cirral anlagen and dorsal kinety anlagen (arrows); arrowheads in (E) indicate left marginal anlagen of proter and opisthe; arrowheads in (F) indicate grandparental dorsal bristles. (G,H) Ventral (G) and dorsal (H) views of a late divider, showing newly formed frontal-ventral-transverse cirri, fused macronuclear mass and micronucleus; arrowheads in (G) mark dorsomarginal kinety anlagen formed near the anterior ends of right marginal anlagen; arrowheads in $\mathbf{( H )}$ indicate grandparental dorsal bristles; arrow marks new caudal cirrus formed at the end of dorsal kinety 3. LMA, left marginal anlagen; Ma, macronuclear nodules; Mi, micronuclei; OP, oral primordium; RMA, right marginal anlagen; I-VI,

frontal-ventral-transverse cirral anlagen; $1-4$, parental dorsal kineties. Scale bars $=50 \mu \mathrm{m}$.

The marginal anlagen develop by dedifferentiation of the parental structures, and the right marginal anlage of the proter appears earlier than others (Figures 5C,E, 6C,D). Then, all the anlagen extend longitudinally and generate new cirri in both proter and opisthe (Figures 5G, 6F).

Dorsal morphogenesis occurs by two groups of primordia: one group develops by dedifferentiation of the parental structures at the middle stage, that is, each of dorsal kineties 1-3 forms an anlage in both proter and opisthe (Figures 5F, 6E, arrows). Later, all the anlagen lengthen at both ends, and one caudal cirrus is generated at the end of dorsal kinety 3 (Figures $\mathbf{5 H}, \mathbf{6 H}$ ). The second group, that is, the dorsomarginal kinety primordia, develops de novo to the anterior right of the right marginal row anlage during the late stage (Figures 5G, 6F, arrowheads). 

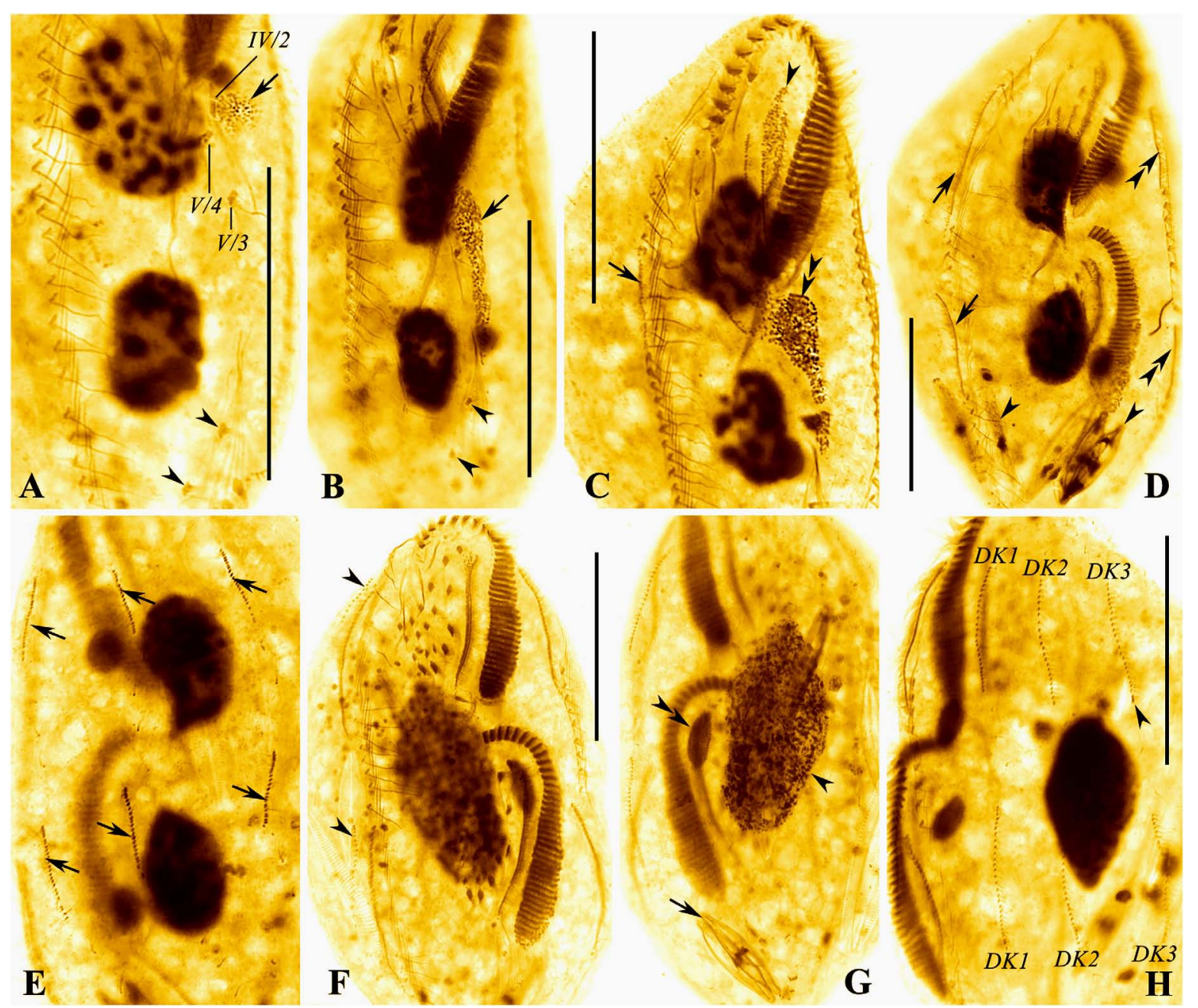

FIGURE 6 | (A-H) Photomicrographs of the Wuhan population of Rubrioxytricha haematoplasma during the ontogenetic process after protargol impregnation. (A,B) Ventral views of very early dividers, showing the formation of oral primordium (arrows); arrowheads indicate pretransverse ventral cirri. (C) Ventral view of an early divider, showing undulating membranes anlage of proter (= anlage I, arrowhead) dedifferentiated from the old structure, right marginal anlage of proter (arrow), and newly formed adoral membranelles of the opisthe (double arrowheads). (D,E) Ventral (D) and dorsal (E) views of a middle divider, showing right marginal anlagen (arrows in D), left marginal anlagen (double arrowheads), and dorsal kinety anlagen (arrows in E); arrowheads mark diatoms in the cell. (F,G) Ventral (F) and dorsal (G) views of a late divider, showing dorsomarginal kinety anlagen (arrowheads) formed near anterior ends of right marginal anlagen, fused macronuclear mass (arrowhead) and micronucleus (double arrowheads); arrow marks diatoms in the cell. (H) Ventral view of a late divider, showing newly formed dorsal kineties and new caudal cirrus (arrowhead) formed at the end of dorsal kinety 3. DK1-3, new dorsal kineties. Scale bars $=50 \mu \mathrm{m}$.

During the late stage of the ontogenetic process, the macronuclear nodules fuse with one another and the micronuclei fuse into a single mass as well (Figures 5H, 6G).

\section{$18 S$ rRNA Gene Sequences and Phylogenetic Analyses}

The 18S rRNA gene sequence of Oxytricha lithofera (excluding both primers) has been deposited in GenBank with accession number MT364897. It has a length of 1,726 bp and a $\mathrm{G}+\mathrm{C}$ content of $45.48 \%$. The closest sequence to $O$. lithofera is Urosoma salmastra (KF951419), with the sequence similarity of $98.3 \%$ (28 nucleotide difference). The $18 \mathrm{~S}$ rRNA gene sequence of Rubrioxytricha haematoplasma (excluding both primers) has been deposited in GenBank with accession number MT364898. It has a length of 1,724 bp and a $\mathrm{G}+\mathrm{C}$ content of $45.01 \%$. The $18 \mathrm{~S}$ rRNA gene sequences of all six Rubrioxytricha isolates differ from each other by 0 to 26 nucleotides, with sequence identities from 98.4 to $100 \%$ (Table 2 ).

In the phylogenetic trees, Oxytricha species are separated into several clades. Oxytricha lithofera is sister to U. salmastra (KF951419) and distant from the type species of the genus, O. granulifera (AF508762), and O. granulifera chiapasensis (KX889988) although this relationship is not robust as indicated by the low support in the ML tree (ML/BI, $54 \% / 1.00)$. All species of Rubrioxytricha fall within a wellsupported assemblage (ML/BI, 91\%/1.00) although this genus 


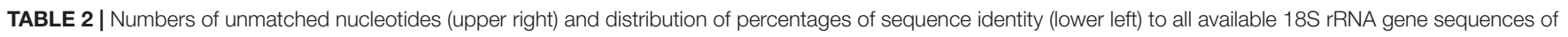
Rubrioxytricha species.

\begin{tabular}{|c|c|c|c|c|c|c|}
\hline Species (accession number) & 1 & 2 & 3 & 4 & 5 & 6 \\
\hline 1. R. haematoplasma (MT364898) & - & 1 & 1 & 6 & 9 & 20 \\
\hline 2. R. tsinlingensis (KR817675) & 0.999 & - & 0 & 5 & 10 & 21 \\
\hline 3. Rubrioxytricha sp. (MG603612) & 0.999 & 1.000 & - & 5 & 10 & 21 \\
\hline 4. R. ferruginea (AF370027) & 0.996 & 0.996 & 0.996 & - & 15 & 26 \\
\hline 5. R. guamensis (KY947508) & 0.994 & 0.993 & 0.993 & 0.990 & - & 17 \\
\hline 6. R. guangzhouensis spec. nov. (KJ645977) & 0.987 & 0.987 & 0.987 & 0.984 & 0.989 & - \\
\hline
\end{tabular}

is not monophyletic as two sequences under the names of Polystichothrix monilata (KT192639) and Pseudogastrostyla flava (KP266627) nest within it. Rubrioxytricha guamensis (KY947508) and R. guangzhouensis spec. nov. (KJ645977) branched off first in the large assemblage. The new sequence $R$. haematoplasma (MT364898) is most closely related with a cluster including three congeners, $R$. tsinlingensis (KR817675), Rubrioxytricha sp. (MG603612), and R. ferruginea (AF370027). However, the sister relationship between the four abovementioned species of Rubrioxytricha and the group of PolystichothrixPseudogastrostyla does not receive high support in the ML tree (ML/BI, 59\%/1.00). The morphological hypothesis that Rubrioxytricha is a monophyletic group was rejected by the AU test $\left(p\right.$ value $\left.=4 \times 10^{-17}\right)$.

\section{DISCUSSION}

\section{Identification of the Chinese Population of Oxytricha lithofera and Emended Diagnosis of the Species}

Based on a population collected from Golfete de Cuare del Indio (salinity 10\%0), Venezuela, Foissner (2016) reported a highly distinctive species, O. lithofera, with a combination of features not present in any other Oxytricha species. Our population, collected from a sandy beach (salinity 3-6\% ) of Zhuhai, shares most of the following typical features with the Venezuelan population: (1) cirral pattern; (2) straight and parallel undulating membranes; (3) abutting macronuclear nodules, usually with a globular micronucleus attached to each; (4) large lithosomes present; (5) dorsal bristles increasing in length from the anterior end to the posterior end of dorsal kineties, up to $10 \mu \mathrm{m}$ long; and (6) mitochondria-like granules present. Compared with the type population, the Zhuhai population has (1) a relatively larger body size in vivo $(80-115 \times 25-$ 40 vs. $60-85 \times 23-32 \mu \mathrm{m})$ and after protargol impregnation (60-105 × 29-51 vs. 53-75 × 20-28 $\mu \mathrm{m})$ (shrinkage differed between the two methods); (2) more adoral membranelles (21-29 vs. 19-21); and (3) more marginal cirri (left, $14-18$ vs. 1215; right, 13-16 vs. 9-12). However, all of these differences, most of which overlap with each other, can be considered as population-dependent geographic variations (Berger, 1999; Chen et al., 2020). One difference that cannot be ignored is that there is a one-bristle-wide gap in dorsal kinety 1 of the type population, while the gap in most of the specimens of the Zhuhai population is absent. This may be seen as an intraspecific or intrapopulational difference. Therefore, we consider the Zhuhai population conspecific with the Venezuelan population. Based on the information of the Zhuhai population and the type population, an emended diagnosis is supplied here.

\section{Emended Diagnosis of Oxytricha lithofera}

Size $60-115 \times 23-40 \mu \mathrm{m}$ in vivo; body usually elongate ellipsoid. Mitochondria-like cortical granules present, globular, about 1.0-1.5 $\mu \mathrm{m}$ across. One, two, or three ring-shaped lithosomes, located subapically and/or subterminally. Adoral zone about $39 \%$ of body length, with about 23 membranelles. Undulating membranes straight, optically side by side. Eighteen frontoventral, transverse cirri. Six dorsal kineties with two dorsomarginal rows included, dorsal bristles gradually increasing in length from the anterior end to the posterior end. Three conspicuous caudal cirri. Two abutting ellipsoid macronuclear nodules and two globular micronuclei. Brackish habitat.

\section{Identification of the Populations of Rubrioxytricha haematoplasma}

Hitherto, five Rubrioxytricha species have been reported, namely $R$. haematoplasma, R. ferruginea, R. indica, R. tsinlingensis, and R. guamensis (Berger, 1999; Naqvi et al., 2006; Chen et al., 2017; Kumar et al., 2018). The type species of the genus, $R$. haematoplasma, was originally reported by Blatterer and Foissner (1990) based on a German population. Subsequently, Shin and Kim (1993) described a Korean population. Recently, Chen et al. (2015) reported a brackish/marine population collected from Guangzhou, China, based on detailed morphological, morphogenetic, and phylogenetic analyses.

The main features of the Wuhan population correspond well with those of the type population of $R$. haematoplasma, e.g., body shape, cirral pattern, dorsal ciliature, especially the color of cortical granules and cytoplasm. There is a tiny difference in terms of the distribution pattern of cortical granules, that is, the cortical granules of the type population are arranged in regular lines as shown in the drawings (Figure $5 \mathrm{~d}$ in Blatterer and Foissner, 1990), while the cortical granules in the Wuhan population seem more or less irregular, with some in small groups and then in long lines. In addition, the postoral ventral cirri in the type population are distributed in a line, while those in the Wuhan population are in a $\mathrm{V}$ pattern. 
However, we consider that these differences are not enough to separate them as different species. The Wuhan population of $R$. haematoplasma can be easily distinguished from the other four congeners by the characteristics shown in Table 3, while the differences of the 18S rRNA gene sequences of the five Rubrioxytricha members ranges from 1 to 20 nucleotides (Table 2). It is noteworthy that there is only one nucleotide difference of the $18 \mathrm{~S}$ rRNA gene between $R$. haematoplasma and $R$. tsinlingensis, while morphologically, they have distinct different dorsal ciliature (four dorsal kineties with only one caudal cirrus vs. six dorsal kineties with three caudal cirri) (Table 3). The highly conserved nature of the 18S rRNA gene has been noted in other oxytrichid morphospecies as well (Kumar et al., 2017; Fan et al., 2021). Thus, the Wuhan population can be identified as $R$. haematoplasma.

There was no information about cortical granules or cytoplasm color of the Korean population (Shin and Kim, 1993). The differences in numbers of adoral membranelles and in the dorsal ciliature were considered as geographical variations by Berger (1999) and population differences by Chen et al. (2015). Herein, we tentatively accept these opinions until more information (cortical granules, cytoplasm, molecular data) is available for the Korean population.

Chen et al. (2015) did mention that the paroral and endoral membranes of the Guangzhou population of $R$. haematoplasma are more curved than those of the type population. However, this might be a preparation artifact, because photomicrographs of live specimens do not show a wide and deep buccal cavity as discussed by Kumar et al. (2018), and the undulating membranes of the early dividers (Figures 3a,b in Chen et al., 2015) do not show a strong degree of curvature either. Therefore, there is no distinct difference of the undulating membranes among the populations, all of which are arranged in an Australocirrus pattern. Compared with the Guangzhou population described by Chen et al. (2015), the Wuhan population and the type population of $R$. haematoplasma show significant differences in the following aspects: (1) cortical granules (lemon yellowish to greenish in color vs. reddish-brown), (2) mitochondria-like granules (absent vs. present), (3) color of the cytoplasm (slightly orange vs. slightly red), and (4) the habitat (freshwater vs. brackish/marine) (Table 3). Hence, we consider the Guangzhou population as a different species from $R$. haematoplasma. Furthermore, the $18 \mathrm{~S}$ rRNA gene sequences (20 nucleotide difference between the Wuhan and the Guangzhou populations, Table 2) indicate that these two populations represent separate species.

In terms of cytoplasm color, cortical granules, cirral pattern, and dorsal ciliature, the Guangzhou population of $R$. haematoplasma should be compared with the other four species of the genus. The Guangzhou population of $R$. haematoplasma can be distinguished from all the others by the color of cortical granules (reddish-brown vs. $R$. ferruginea, brownish; $R$. guamensis, yellowish; $R$. indica, dark green; $R$. tsinlingensis, yellow-green) and the presence of mitochondrialike granules (vs. absent in all the congeners). For more differences among all the species, see Table 3 . Thus, the Guangzhou population represents a separate species of the genus Rubrioxytricha.

\section{Establishment of a New Rubrioxytricha Species Rubrioxytricha guangzhouensis spec. nov. (Figures 7A-J)}

2015 Rubrioxytricha haematoplasma (Blatterer and Foissner, 1990) Berger, 1999 - Chen et al., Int. J. Syst. Evol. Microbiol., 65, 309-320.

\section{Remarks}

As discussed above, a new species should be established for the Guangzhou isolate which was described under the name R. haematoplasma by Chen et al. (2015).

Chen et al. (2015) stated "the Chinese population came from two shrimp-farming ponds, one brackish (salinity $8.6 \%$ ) and the other marine $(34.4 \%$ ). However, the brackish water was created artificially by mixing together marine and freshwater, and material was regularly transferred between the two ponds, so it is unclear whether the Chinese population of $R$. haematoplasma was originally from a marine or a freshwater habitat." We think it is possible that the Guangzhou isolate was originally from the marine pond and then transferred to the brackish pond. Therefore, we tentatively treat the marine pond as the type locality.

\section{Diagnosis}

Size 90-180 × 30-70 $\mu \mathrm{m}$ in vivo; body elongate oval, brownreddish in color. Cortical granules, approximately $0.8 \mu \mathrm{m}$ in diameter, reddish-brown, grouped in lines on dorsal; mitochondria-like granules about $3 \mu \mathrm{m}$ in diameter, colorless and spherical, densely packed. Adoral zone about $30 \%$ of body length, with about 37 membranelles. Eighteen frontoventral, transverse cirri. Three bipolar dorsal kineties and one slightly shorter dorsomarginal row; one caudal cirrus at the posterior end of dorsal kinety 3. Two macronuclear nodules and one to three micronuclei. Brackish/marine habitat.

\section{Etymology}

The species-group name guangzhouensis refers to the geographic locality where the ciliate population was discovered.

\section{Type Locality}

Marine shrimp-farming pond (salinity 34\%0) at the campus of the South China Normal University, Guangzhou, China $\left(23^{\circ} 08^{\prime} 19^{\prime \prime} \mathrm{N} ; 113^{\circ} 21^{\prime} 22^{\prime \prime} \mathrm{E}\right)$.

\section{Type Specimens}

The protargol-stained slide containing the holotype specimen (Figures 7C-E) and 10 paratype slides were deposited in the Laboratory of Protozoology, OUC, China, with registration numbers CXM08112701-01 11.

\section{ZooBank Registration}

Rubrioxytricha guangzhouensis spec. nov. is registered in ZooBank under: urn:lsid:zoobank.org:act:036912E2-4662-40D1B666-B4091FD50DE1. 
TABLE 3 | Morphological and morphometric comparison of Rubrioxytricha species.

\begin{tabular}{|c|c|c|c|c|c|c|c|c|}
\hline Character & $\begin{array}{l}\text { Rubrioxytricha } \\
\text { haematoplasma }\end{array}$ & $\begin{array}{c}\text { Rubrioxytricha } \\
\text { haematoplasma }\end{array}$ & $\begin{array}{c}\text { Rubrioxytricha } \\
\text { haematoplasma }\end{array}$ & $\begin{array}{l}\text { Rubrioxytricha } \\
\text { guangzhouensis } \\
\text { spec. nov. }\end{array}$ & $\begin{array}{l}\text { Rubrioxytricha } \\
\text { ferruginea }\end{array}$ & $\begin{array}{l}\text { Rubrioxytricha } \\
\text { guamensis }\end{array}$ & $\begin{array}{c}\text { Rubrioxytricha } \\
\text { indica }\end{array}$ & $\begin{array}{c}\text { Rubrioxytricha } \\
\text { tsinlingensis }\end{array}$ \\
\hline $\mathrm{BL}^{a}(\mu \mathrm{m})$ & $125-160$ & $120-180$ & $100-180$ & $90-180$ & $150-200$ & $85-110$ & 80 & $100-180$ \\
\hline $\mathrm{BW}^{\mathrm{a}}(\mu \mathrm{m})$ & $40-60$ & $40-55$ & $50-90$ & $30-70$ & / & $25-45$ & 30 & $35-60$ \\
\hline $\mathrm{BL}^{b}(\mu \mathrm{m})$ & $122-175$ & $91-143$ & $112-160$ & 133-195 & $122-162$ & $74-96$ & $65-74$ & $144-186$ \\
\hline $\mathrm{BW}^{b}(\mu \mathrm{m})$ & $45-74$ & $29-51$ & $42-80$ & 50-95 & $39-51$ & $20-38$ & $24-32$ & $64-89$ \\
\hline $\mathrm{AZM}, n$ & $34-41$ & $30-48$ & $21-30$ & $33-45$ & $35-41$ & 23-32 & $27-31$ & $36-44$ \\
\hline $\mathrm{CC}, n$ & 1 & $0.8(0-1)$ & $0.7(0-1)$ & 1 & $1.7(1-2)$ & $1.1(1-2)$ & 1 & 3 \\
\hline $\mathrm{DK}, n$ & 4 & 4 & $4.1(4-5)$ & 4 & 5 & 4 & 5 & 6 \\
\hline $\mathrm{DM}, n$ & 1 & 1 & 1 & 1 & / & 1 & 2 & / \\
\hline DKF & Absent & Absent & Absent & Absent & / & Absent & Absent & / \\
\hline Cortical granules & $\begin{array}{l}\text { Lemon yellowish to } \\
\text { greenish }\end{array}$ & $\begin{array}{l}\text { Lemon yellowish to } \\
\text { greenish }\end{array}$ & / & Reddish-brown & Brownish & Yellowish & Dark green & Yellow-green \\
\hline Color of the cytoplasm & Slightly orange & $\begin{array}{l}\text { Slightly orange to } \\
\text { reddish }\end{array}$ & / & Slightly red & Rusty & Colorless & $\begin{array}{l}\text { More or less } \\
\text { colorless }\end{array}$ & Slightly brown \\
\hline Color of the cell & $\begin{array}{l}\text { Yellow-brown to } \\
\text { slightly darkish }\end{array}$ & $\begin{array}{l}\text { Darkish at low } \\
\text { magnification }\end{array}$ & / & $\begin{array}{l}\text { Dark-brownish to } \\
\text { ashblack }\end{array}$ & Rusty brown & / & / & Yellow-brown \\
\hline Habitat & Freshwater pond & Freshwater river & Freshwater river & Brackish/marine & Eutrophic pond & Freshwater pond & & Freshwater pond \\
\hline Data source & Present work & $\begin{array}{c}\text { Blatterer and } \\
\text { Foissner (1990); } \\
\text { Berger (1999) }\end{array}$ & $\begin{array}{l}\text { Shin and Kim } \\
\text { (1993) }\end{array}$ & Chen et al. (2015) & $\begin{array}{c}\text { Song and Wilbert } \\
\text { (1989); Berger } \\
\text { (1999) }\end{array}$ & Kumar et al., 2018 & Naqvi et al. (2006) & Chen et al. (2017) \\
\hline
\end{tabular}

Characters marked with "/" were not available from the source cited. Abbreviations: AZM, adoral zone of membranelles; BL, body length; BW, body width; CC, caudal cirri; DK, dorsal kineties; DKF, dorsal kinety fragmentation; DM, dorsomarginal kineties; $n$, number. ${ }^{a}$ Data based on specimens in vivo. ${ }^{b}$ Data based on specimens after protargol impregnation. 


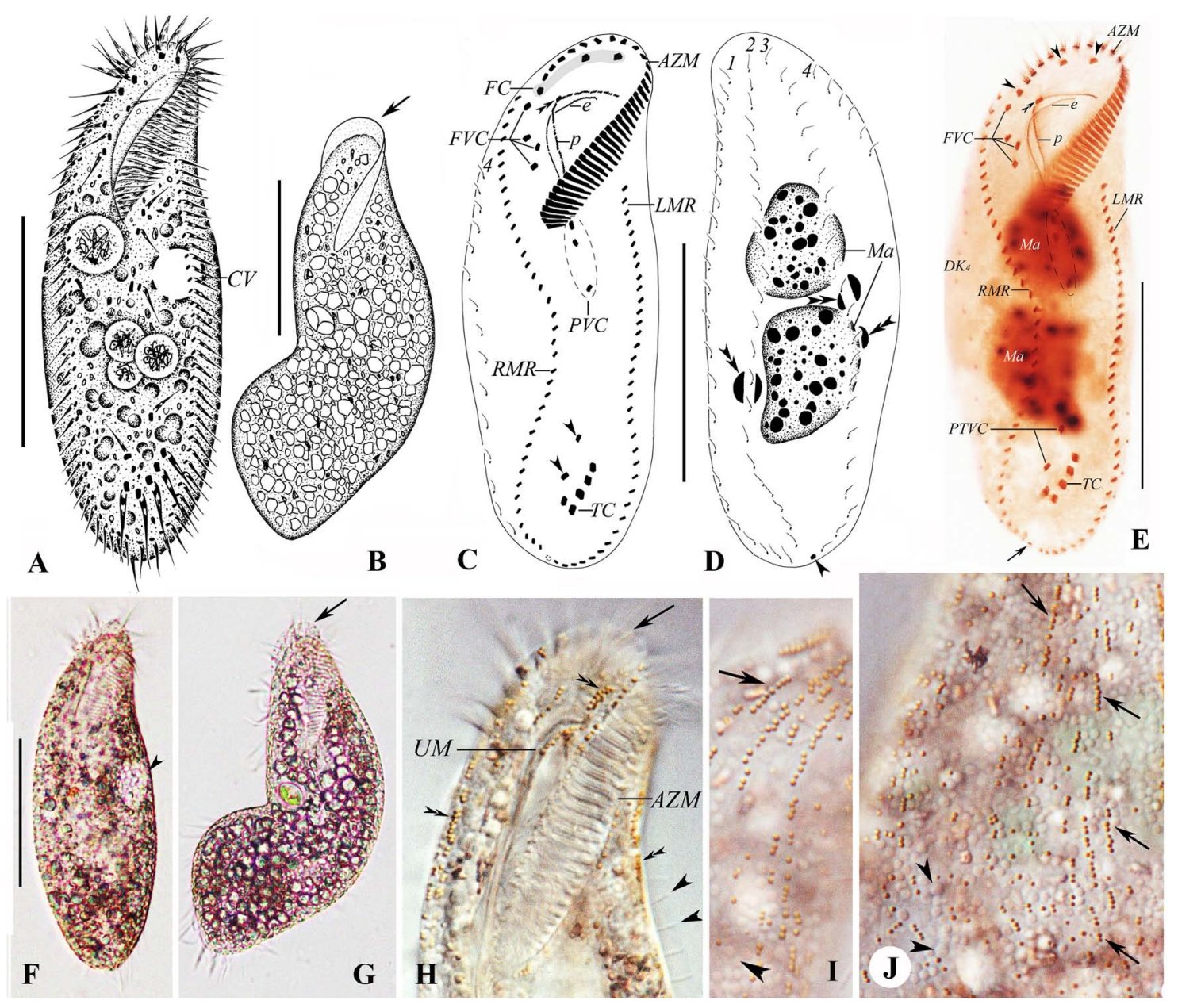

FIGURE 7 | (A-J) Morphology and ciliature of Rubrioxytricha guangzhouensis spec. nov. from life (A,B,F,G, bright field; $\mathbf{H}-\mathbf{J}$, differential interference contrast) and after protargol impregnation (C-E). (A-J) From Chen et al. (2015). (A) Ventral view of a representative individual. (B) Ventral view of a bending cell to show the flexibility of the body; arrow marks the frontal scutum. (C-E) Ventral (C,E) and dorsal (D) views of the holotype specimen, showing ciliature and nuclear apparatus; arrowheads in (C) mark pretransverse ventral cirri; double arrowheads in (C,E) mark buccal cirrus; double arrowheads in (D) show micronuclei; arrow in (D,E) indicates the single caudal cirrus; arrows in (E) show frontal cirri. (F) Ventral view of the typical individual; arrowhead marks the contractile vacuole. (G) Ventral view of bending cell to show the flexibility of the body; arrow marks the transparent membrane-like structure at the anterior part of the adoral zone. (H) Ventral view of anterior cell part; arrow marks the transparent membrane-like structure at the anterior part of the adoral zone; double arrowheads indicate the reddish-brown, spherical, type-I cortical granules; arrowheads indicate the dorsal bristles. (I,J) Dorsal views of the anterior (I) and middle (J) cell parts; arrows indicate the reddish-brown, spherical, type-I cortical granules arranged in lines; arrowheads mark the colorless, densely distributed, mitochondria-like granules. AZM, adoral zone of membranelles; CV, contractile vacuole; e, endoral membrane; FC, frontal cirri; FVC, frontoventral cirri; LMR, left marginal row; Ma, macronuclear nodules; $p$, paroral membrane; PVC, postoral ventral cirri; RMR, right marginal row; TC, transverse cirri; UM, undulating membranes; $1-4$, dorsal kineties. Scale bars = $60 \mu \mathrm{m}$.

\section{Morphogenetic Comparison of Rubrioxytricha Species}

Blatterer and Foissner (1990) gave an incomplete morphogenetic description for the type population of $R$. haematoplasma. In the present study, we supply somewhat more detailed morphogenetic information for $R$. haematoplasma based on the Wuhan population. Chen et al. (2015) provided a detailed morphogenetic description for R. guangzhouensis spec. nov. Naqvi et al. (2006) reported the morphogenetic process of $R$. indica and Kumar et al. (2018) provided brief notes on the ontogenesis of R. guamensis. All the abovementioned populations share the following morphogenetic features: (1) the parental adoral zone of membranelles is completely inherited, unchanged, by the proter; (2) the undulating membranes anlage of the proter originates by dedifferentiation of the parental structures; (3) parental buccal cirrus (II/2), two frontoventral cirri (III/2, IV/3), and three postoral ventral cirri (IV/2, V/3, V/4) contribute to the formation of the anlagen; (4) the frontal-ventral-transverse (FVT) cirral anlagen are probably formed via a primary pattern and the FVT cirri are formed in a typical Oxytricha pattern, i.e., in the pattern of 1:3:3:3:4:4 from left to right; (5) marginal anlagen develop intrakinetally within the parental structures; (6) dorsal kineties are formed in the Urosomoida pattern, i.e., dorsomarginal row present and without fragmentation of kinety 3; (7) a single caudal cirrus (seldom two caudal cirri 


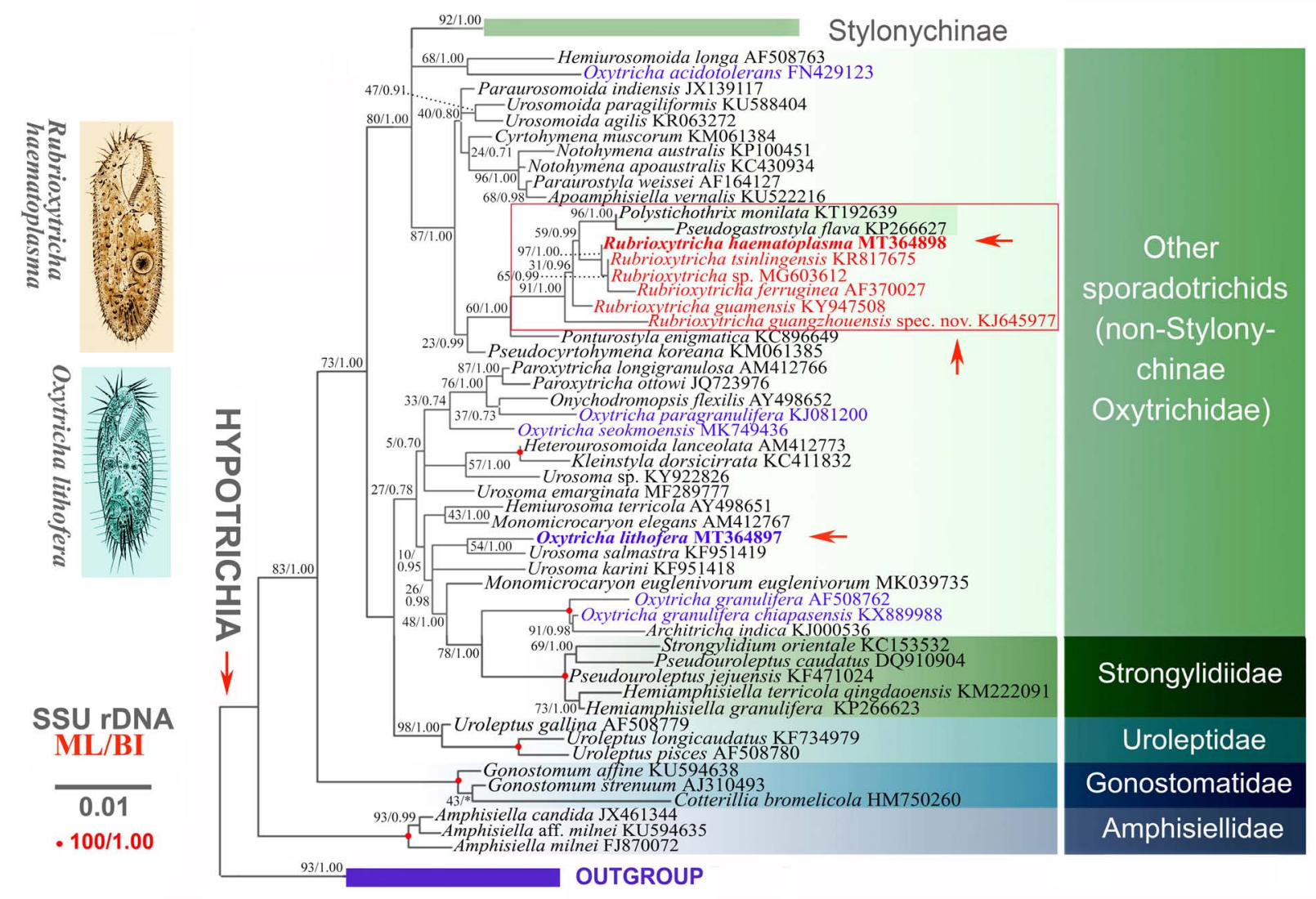

FIGURE 8 | Maximum likelihood (ML) phylogenetic tree inferred from the 18S rRNA gene sequences. Numbers near nodes represent the ML bootstrap values and Bayesian posterior probabilities. Nodes designated by an asterisk correspond to the supports not recovered in the estimated BI tree. For both trees, the scale bar corresponds to 0.01 expected substitutions per site. New sequences provided in the present work are indicated in bold.

in $R$. guamensis) originates at the end of dorsal kinety 3; and (8) two macronuclear nodules fuse into a single mass during the morphogenetic process. This combination of features reveals a highly conservative morphogenetic pattern of the above Rubrioxytricha species (Naqvi et al., 2006; Chen et al., 2015; Song and Shao, 2017; Kumar et al., 2018).

\section{Phylogenetic Analyses}

As described in previous studies, Oxytricha and Urosoma species are irregularly distributed over the phylogenetic trees, revealing that both the genus Oxytricha and Urosoma are nonmonophyletic and lack obvious synapomorphies (Schmidt et al., 2007; Paiva et al., 2009; Shao et al., 2014, 2019; Gao et al., 2016; Jung and Berger, 2019; Kaur et al., 2019; Kim and Min, 2019; Dong et al., 2020; Wang et al., 2020b; Xu et al., 2020). In the present phylogenetic trees (Figure 8), O. lithofera is placed sister to U. salmastra (KF951419). Morphologically, they do have the same features as follows: flexible body, single marginal row on each body side, three caudal cirri, two macronuclear nodules, and two micronuclei, which, however, are shared by most of the oxytrichids (Berger, 1999; Wang et al., 2017). Moreover, O. lithofera can be easily distinguished from U. salmastra by an adoral zone of membranelles more or less in Stylonychia pattern (vs. typical Gonostomum pattern), having more transverse cirri (five vs. four), and more dorsal kineties (six, kinety fragmentation probably present vs. four, kinety fragmentation absent), which all have been considered as genus-level diagnostic features for the oxytrichids (Berger, 1999; Shao et al., 2015; Wang et al., 2020b). In addition, the grouping of O. lithofera and U. salmastra is far from stable as this relationship does not receive high support in the ML analysis. The topology may very likely be changed when additional molecular data from more taxa are available.

All species of Rubrioxytricha are intermingled with P. monilata (KT192639) and P. flava (KP266627) in a highly supported assemblage, indicating that Rubrioxytricha is paraphyletic. The hypothesis that Rubrioxytricha species form a monophyletic group was rejected by the AU test, although the internal relationships are not yet robustly resolved. The close relationship between Rubrioxytricha and Polystichothrix-Pseudogastrostyla is morphologically supported as they all have a flexible body, one marginal row on each body side, and brightly colored cortical granules. However, Rubrioxytricha differs significantly from Polystichothrix and Pseudogastrostyla in having a typical oxytrichid pattern of 18 FVT cirri (vs. more than 18 FVT cirri in short lines) (Fan et al., 2015; Luo et al., 2017). The phylogenetic placement 
of the genera Polystichothrix and Pseudogastrostyla might be explained by the assumption that those taxa with more than 18 FVT cirri evolved by a secondary increase in the numbers of FVT anlagen and/or additional cirri originated from some of the anlagen (Berger, 1999; Luo et al., 2017). Moreover, the dorsal ciliature pattern, which also carries an informative phylogenetic signal, like the ventral cirral pattern (Berger, 1999; Shao et al., 2011, 2015; Foissner, 2016), shows great variety in the Rubrioxytricha-Polystichothrix-Pseudogastrostyla clade: (1) four dorsal kineties in $R$. guamensis, $R$. haematoplasma, $R$. indica, $R$. guangzhouensis spec. nov., and Pseudogastrostyla, with one dorsomarginal kinety present, dorsal kinety fragmentation absent, only one caudal cirrus (seldom two caudal cirri in R. guamensis) present at the end of dorsal kinety 3; (2) five dorsal kineties in $R$. ferruginea and Polystichothrix, very likely including one dorsomarginal kinety and dorsal kinety 4 originated by dorsal kinety 3 fragmentation, one or two caudal cirri present in $R$. ferruginea and caudal cirri lacking in Polystichothrix; (3) six dorsal kineties in $R$. tsinlingensis, probably with two dorsomarginal rows included and dorsal kinety 4 originated by dorsal kinety 3 fragmentation, three caudal cirri in total, one each at the posterior end of dorsal kineties 1, 2, and 4 (Berger, 1999; Naqvi et al., 2006; Chen et al., 2015, 2017; Fan et al., 2015; Luo et al., 2017; Kumar et al., 2018).

The incongruence between morphology and molecular data suggests that Oxytricha and Rubrioxytricha are genera with high genetic divergence, which need to be broken up into multiple new genera. At present, there are over 1,000 nominal hypotrich ciliates (Chen et al., 2017); however, the 18S rRNA gene sequences are only available for about $30 \%$ of this group (NCBI database). Thus, molecular data from additional taxa and even

\section{REFERENCES}

Berger, H. (1999). Monograph of the Oxytrichidae (Ciliophora, Hypotrichia). Dordrecht: Springer Netherlands.

Berger, H. (2008). Monograph of the Amphisiellidae and Trachelostylidae (Ciliophora, Hypotricha). Berlin: Springer Science \& Business Media.

Blatterer, H., and Foissner, W. (1990). Beiträge zur ciliatenfauna (Protozoa: Ciliophora) der Amper (Bayern, Bundesrepublik Deutschland). Arch. Protistenkd. 138, 93-115. doi: 10.1016/s0003-9365(11)80148-x

Chen, L., Dong, J., Wu, W., Xin, Y., Warren, A., Ning, Y., et al. (2020). Morphology and molecular phylogeny of a new hypotrich ciliate, Anteholosticha songi nov. spec., and an American population of Holosticha pullaster (Müller, 1773) Foissner et al., 1991 (Ciliophora, Hypotrichia). Eur. J. Protistol. 72:125646. doi: 10.1016/j.ejop.2019.125646

Chen, L., Zhao, X., Shao, C., Miao, M., and Clamp, J. (2017). Morphology and phylogeny of two new ciliates, Sterkiella sinica sp. nov. and Rubrioxytricha tsinlingensis sp. nov. (Protozoa, Ciliophora, Hypotrichia) from north-west China. Syst. Biodivers. 15, 131-142. doi: 10.1080/14772000.2016.1219426

Chen, W., Chen, X., Li, L., Warren, A., and Lin, X. (2015). Morphology, morphogenesis and molecular phylogeny of an oxytrichid ciliate, Rubrioxytricha haematoplasma (Blatterer \& Foissner, 1990) Berger, 1999 (Ciliophora, Hypotricha). Int. J. Syst. Evol. Microbiol. 65, 309-320. doi: $10.1099 / \mathrm{ijs} .0 .067801-67800$

Dong, J., Li, L., Fan, X., Ma, H., and Warren, A. (2020). Two Urosoma species (Ciliophora, Hypotrichia): a multidisciplinary approach provides new insights into their ultrastructure and systematics. Eur. J. Protistol. 72:125661. doi: 10. 1016/j.ejop.2019.125661

Fan, X., Yao, S., Luo, X., Dong, T., Xu, Y., Chen, L., et al. (2021). Some morphologically distinguishable hypotrich ciliates share identical $18 \mathrm{~S}$ rRNA gene sequences - taxonomic insights from a case study on Oxytricha species phylogenomic data are needed to reveal the natural phylogeny of this group of ciliates.

\section{DATA AVAILABILITY STATEMENT}

The original contributions presented in the study are publicly available. This data can be found here: GenBank (https: //www.ncbi.nlm.nih.gov/genbank/) with accession numbers MT364897-MT364898.

\section{AUTHOR CONTRIBUTIONS}

$\mathrm{XL}$ and $\mathrm{JH}$ collected the samples. XL carried out the experiments (live observation, protargol impregnation, and DNA amplification) and analyses (morphometrics and phylogenetic analyses). XC and WS supervised the work. All authors wrote the manuscript and approved the final version.

\section{FUNDING}

This work was supported by the Natural Science Foundation of China (project numbers 31900319, 31772433, and 32030015), the Natural Science Foundation of Shandong Province (project number: ZR2019QD015), the Deanship of Scientific Research at King Saud University (RSP-2021/7), the Youth Innovation Promotion Association of the CAS (No. 2019333), and the China Postdoctoral Science Foundation Grant (Nos. BX20180348 and 2018M642955).

(Protista, Ciliophora). Zool. J. Linn. Soc. doi: 10.1093/zoolinnean/zlaa145 [Epub ahead of print].

Fan, Y., Zhao, X., Hu, X., Miao, M., Warren, A., and Song, W. (2015). Taxonomy and molecular phylogeny of two novel ciliates, with establishment of a new genus, Pseudogastrostyla n. g. (Ciliophora, Hypotrichia, Oxytrichidae). Eur. J. Protistol. 51, 374-385. doi: 10.1016/j.ejop.2015.06.007

Foissner, W. (2016). Terrestrial and semiterrestrial ciliates (Protozoa, Ciliophora) from Venezuela and Galápagos. Denisia 35, 1-912. doi: 10.1007/978-3-31923534-9_1

Foissner, W., Agatha, S., and Berger, H. (2002). Soil ciliates (Protozoa, Ciliophora) from Namibia (Southwest Africa), with emphasis on two contrasting environments, the Etosha region and the Namib Desert. Denisia 5, 1-1459. doi: 10.1007/978-3-319-23534-9_1

Gao, F., Warren, A., Zhang, Q., Gong, J., Miao, M., Sun, P., et al. (2016). The all-data-based evolutionary hypothesis of ciliated protists with a revised classification of the phylum Ciliophora (Eukaryota, Alveolata). Sci. Rep. 6:24874. doi: 10.1038/srep24874

Gouy, M., Guindon, S., and Gascuel, O. (2010). SeaView version 4: a multiplatform graphical user interface for sequence alignment and phylogenetic tree building. Mol. Biol. Evol. 27, 221-224. doi: 10.1093/molbev/msp259

Hall, T. A. (1999). BioEdit: a user-friendly biological sequence alignment editor and analysis program for windows 95/98/NT. Nucleic Acids Symp. Ser. 41, 95-98.

$\mathrm{Hu}$, X., Lin, X., and Song, W. (2019). Ciliates Atlas: Species Found in the South China Sea. Beijing: Science Press.

Jung, J. H., and Berger, H. (2019). Monographic treatment of Paraholosticha muscicola (Ciliophora, Keronopsidae), including morphological and molecular biological characterization of a brackish water population from Korea. Eur. J. Protistol. 68, 48-67. doi: 10.1016/j.ejop.2018.12.004

Kaur, H., Shashi, Negi, R. K., and Kamra, K. (2019). Morphological and molecular characterization of Neogastrostyla aqua nov. gen., nov. spec. (Ciliophora, 
Hypotrichia) from river Yamuna, Delhi; comparison with Gastrostyla-like genera. Eur. J. Protistol. 68, 68-79. doi: 10.1016/j.ejop.2019.01.002

Kim, K. S., and Min, G. S. (2019). Morphology and molecular phylogeny of Oxytricha seokmoensis sp. nov. (Hypotrichia: Oxytrichidae), with notes on its morphogenesis. Eur. J. Protistol. 71:125641. doi: 10.1016/j.ejop.2019.125641

Kim, K. S., Jung, J. H., and Min, G. S. (2019). Morphology and molecular phylogeny of two new terrestrial ciliates, Australocirrus rubrus n. sp. and Notohymena gangwonensis n. sp. (Ciliophora: Oxytrichidae), from South Korea. J. Eukaryot. Microbiol. 66, 740-751. doi: 10.1111/jeu.12718

Kumar, S., and Foissner, W. (2015). Biogeographic specializations of two large hypotrich ciliates: Australocirrus shii and A. australis and proposed synonymy of Australocirrus and Cyrtohymenides. Eur.J. Protistol. 51, 210-228. doi: 10. 1016/j.ejop.2015.02.002

Kumar, S., Bharti, D., Kabir, A. S., Hong, J. S., and Shin, M. K. (2018). Rubrioxytricha guamensis nov. spec. (Ciliophora, Spirotricha), a novel hypotrich ciliate from Guam (United States), Micronesia. J. Eukaryot. Microbiol. 65, 392-399. doi: 10.1111/jeu.12484

Kumar, S., Bharti, D., Shazib, S. U. A., and Shin, M. K. (2017). Discovery of a new hypotrich ciliate from petroleum contaminated soil. PLoS One 12:e178657. doi: 10.1371/journal.pone. 0178657

Lu, X., Huang, J., Shao, C., and Berger, H. (2018). Morphology, cell-division, and phylogeny of Schmidingerothrix elongata spec. nov. (Ciliophora, Hypotricha), and brief guide to hypotrichs with Gonostomum-like oral apparatus. Eur. J. Protistol. 62, 24-42. doi: 10.1016/j.ejop.2017.11.001

Luo, X., Gao, F., Yi, Z., Pan, Y., Al-Farraj, S. A., and Warren, A. (2017). Taxonomy and molecular phylogeny of two new brackish hypotrichous ciliates, with the establishment of a new genus (Ciliophora, Spirotrichea). Zool. J. Linn. Soc. 179, 475-491. doi: 10.1111/zoj.12451

Luo, X., Yan, Y., Shao, C., Al-Farraj, S. A., Bourland, W. A., and Song, W. (2018). Morphological, ontogenetic, and molecular data support strongylidiids as being closely related to Dorsomarginalia (Protozoa, Ciliophora) and reactivation of the family Strongylidiidae Fauré-Fremiet, 1961. Zool. J. Linn. Soc. 184, 237-254. doi: 10.1093/zoolinnean/zly001

Lynn, D. H. (2008). The Ciliated Protozoa: Characterization, Classification, and Guide to the Literature, Third Edn. New York: Springer Press.

Medlin, L., Elwood, H. J., Stickel, S., and Sogin, M. L. (1988). The characterization of enzymatically amplified eukaryotes $16 \mathrm{~S}$-like ribosomal RNA coding regions. Gene 71, 491-500. doi: 10.1016/0378-1119(88)90066-2

Miller, M. A., Pfeiffer, W., and Schwartz, T. (2010). Creating the CIPRES science gateway for inference of large phylogenetic trees. Gatew. Comput. Environ. Work 1-8.

Naqvi, I., Gupta, R., Borgohain, P., and Sapra, G. R. (2006). Morphology and morphogenesis of Rubrioxytricha indica n. sp. (Ciliophora: Hypotrichida). Acta Protozool. 45, 53-64.

Nylander, J. A. A. (2004). MrModeltest 2.2. Program Distributed by the Author. Uppsala: Evolutionary Biology Centre, Uppsala University.

Paiva, T. S., Borges, B. N., Harada, M. L., and Silva-Neto, I. D. (2009). Comparative phylogenetic study on Stichotrichia (Alveolata: Ciliophora: Spirotrichea) based on 18S-rDNA sequences. Genet. Mol. Res. 8, 223-246. doi: 10.4238/vol81 gmr529

Ronquist, F., Teslenko, M., van der Mark, P., Ayres, D. L., Darling, A., Höhna, S., et al. (2012). MrBayes 3.2: efficient Bayesian phylogenetic inference and model choice across a large model space. Syst. Biol. 61, 539-542. doi: 10.1093/sysbio/ sys029

Schmidt, S. L., Bernhard, D., Schlegel, M., and Foissner, W. (2007). Phylogeny of the Stichotrichia (Ciliophora; Spirotrichea) reconstructed with nuclear small subunit rRNA gene sequences: discrepancies and accordances with morphological data. J. Eukaryot. Microbiol. 54, 201-209.

Sela, I., Ashkenazy, H., Katoh, K., and Pupko, T. (2015). GUIDANCE2: accurate detection of unreliable alignment regions accounting for the uncertainty of multiple parameters. Nucl. Acids Res. 43, W7-W14.

Shao, C., Hu, C., Fan, Y., Warren, A., and Lin, X. (2019). Morphology, morphogenesis and molecular phylogeny of a freshwater ciliate, Monomicrocaryon euglenivorum euglenivorum (Ciliophora, Oxytrichidae). Eur. J. Protistol. 68, 25-36. doi: 10.1016/j.ejop.2019.01.001

Shao, C., Lu, X., and Ma, H. (2015). A general overview of the typical 18 frontalventral-transverse cirri Oxytrichidae s. 1. genera (Ciliophora, Hypotrichia). J. Ocean Univ. China 14, 522-532. doi: 10.1007/s11802-015-2482-7

Shao, C., Lv, Z., Pan, Y., Al-Rasheid, K. A. S., and Yi, Z. (2014). Morphology and phylogenetic analysis of two oxytrichid soil ciliates from China, Oxytricha paragranulifera n. sp. and Oxytricha granulifera Foissner and Adam, 1983 (Protista, Ciliophora, Hypotrichia). Int. J. Syst. Evol. Microbiol. 64, 3016-3027. doi: $10.1099 /$ ijs.0.062281-0

Shao, C., Song, W., Al-Rasheid, K. A. S., and Berger, H. (2011). Redefinition and reassignment of the 18-cirri genera Hemigastrostyla, Oxytricha, Urosomoida, and actinotricha (Ciliophora, Hypotricha), and description of one new genus and two new species. Acta Protozool. 50, 263-287.

Shimodaira, H. (2002). An approximately unbiased test of phylogenetic tree selection. Syst. Biol. 51, 492-508. doi: 10.1080/10635150290069913

Shimodaira, H., and Hasegawa, M. (2001). CONSEL: for assessing the confidence of phylogenetic tree selection. Bioinformatics 17, 1246-1247. doi: 10.1093/ bioinformatics/17.12.1246

Shin, M. K., and Kim, W. (1993). New records of three oxytrichid hypotrichs (Ciliophora: Hypotrichida: Oxytrichidae) from the Han river in Seoul. Korea. Korean J. Zool. 36, 223-230.

Song, W., and Shao, C. (2017). Ontogenetic Patterns of Hypotrich Ciliates. Beijing: Science Press. (in Chinese).

Song, W., and Wilbert, N. (1989). Taxonomische untersuchungen an aufwuchsciliaten (Protozoa, Ciliophora) im poppelsdorfer weiher, bonn. Lauterbornia 3, 2-221.

Stamatakis, A. (2014). RAxML version 8: a tool for phylogenetic analysis and post-analysis of large phylogenies. Bioinformatics 30, 1312-1313. doi: 10.1093/ bioinformatics/btu033

Tamura, K., Stecher, G., Peterson, D., Filipski, A., Dudley, J., and Kumar, S. (2013). MEGA6: molecular evolutionary genetics analysis version 6.0. Mol. Biol. Evol. 30, 2725-2729. doi: 10.1093/molbev/mst197

Wang, J., Li, J., and Shao, C. (2020a). Morphology, morphogenesis, and molecular phylogeny of a novel saline soil ciliate, Heterourosomoida sinica n. sp. (Ciliophora, Hypotrichia). Eur. J. Protistol. 73:125666. doi: 10.1016/j.ejop.2019. 125666

Wang, J., Qi, S., Chen, L., Warren, A., Miao, M., and Shao, C. (2017). Morphogenesis of a saline soil ciliate Urosoma salmastra (Dragesco and Dragesco-Kernéis, 1986) Berger, 1999 with notes on the phylogeny of Urosoma (Ciliophora, Hypotrichia). Eur. J. Protistol. 61, 180-193. doi: 10.1016/j.ejop. 2017.08.003

Wang, J., Zhao, Y., Lu, X., Lyu, Z., Warren, A., and Shao, C. (2020b). Does the Gonostomum-patterned oral apparatus in Hypotrichia carry a phylogenetic signal? evidence from morphological and molecular data based on extended taxon sampling using three nuclear genes (Ciliophora, Spirotrichea). Sci. China Life Sci. doi: 10.1007/s11427-020-1667-1663 [Epub ahead of print].

Weisse, T., Moser, M., Scheffel, U., Stadler, P., Berendonk, T., Weithoff, G., et al. (2013). Systematics and species-specific response to $\mathrm{pH}$ of Oxytricha acidotolerans sp. nov. and Urosomoida sp. (Ciliophora, Hypotrichia) from acid mining lakes. Eur. J. Protistol. 49, 255-271. doi: 10.1016/j.ejop.2012.08.001

Wilbert, N. (1975). Eine verbesserte technik der protargolimprägnation für ciliaten. Mikrokosmos 64, 171-179.

Xu, W., Zhao, Y., Pan, B., Liu, Y., Li, Y., Bourland, W. A., et al. (2020). Morphology, morphogenesis, and phylogeny of Urosoma caudata (Ehrenberg, 1833) Berger, 1999 (Ciliophora, Hypotrichia) based on a Chinese population. J. Eukaryot. Microbiol. 67, 76-85. doi: 10.1111/jeu.12756

Zhang, T. T., Fan, X., Gao, F., Al-Farraj, S. A., El-Serehy, H. A., and Song, W. (2019). Further analyses on the phylogeny of the subclass Scuticociliatia (Protozoa, Ciliophora) based on both nuclear and mitochondrial data. Mol. Phylogenet. Evol. 139:106565. doi: 10.1016/j.ympev.2019.106565

Zhang, T. Y., Dong, J., Cheng, T., Duan, L., and Shao, C. (2020). Reconsideration on the taxonomy of the marine ciliate Neobakuella aenigmatica Moon et al., 2019 (Protozoa, Ciliophora, Hypotrichia). Mar. Life Sci. Technol. 2, 97-108. doi: 10.1007/s42995-020-00032-4

Conflict of Interest: The authors declare that the research was conducted in the absence of any commercial or financial relationships that could be construed as a potential conflict of interest.

Copyright $\odot 2021$ Luo, Huang, Bourland, El-Serehy, Al-Farraj, Chen and Song. This is an open-access article distributed under the terms of the Creative Commons Attribution License (CC BY). The use, distribution or reproduction in other forums is permitted, provided the original author(s) and the copyright owner(s) are credited and that the original publication in this journal is cited, in accordance with accepted academic practice. No use, distribution or reproduction is permitted which does not comply with these terms. 